Pawet Duma, Jerzy Piekalski, Agnieszka Latocha, Marta Pietruszka, Krzysztof Jaworski, Maksym Mackiewicz

\title{
Młyn Dolny w Bystrzycy na Pogórzu Kaczawskim. Zanik młynarstwa tradycyjnego w czasach industrializacji
}

\begin{abstract}
Słowa kluczowe: młyn wodny, Pogórze Kaczawskie, industrializacja, ALS
Key words: watermill, Pogórze Kaczawskie, industrialization, ALS
\end{abstract}

Zasadniczym celem podjętym przez autorów artykułu jest prześledzenie postępującego w XIX w. kryzysu młynarstwa opartego na energii koła wodnego. Proces głębokich zmian prowadzących do zaniku młynów wodnych w tradycyjnym kształcie był efektem wprowadzenia nowych źródeł energii. Zjawisko to jest zagadnieniem z zakresu historii powszechnej i nie wymaga dokładnego wyjaśnienia. Natomiast wiedza o tempie i zakresie zmian w wymiarze regionalnym jest skromna. Niewiele wiadomo o przebiegu powolnej modernizacji urządzeń wodnych, który odbywał się ustawicznie od średniowiecza i o próbach dostosowania się do nowych warunków w fazie postępującej industrializacji. Do tej pory nie zajmowano się tym problemem szczegółowo, a jak się wydaje, jest on fascynujący i zawiera wiele wątków odnoszących się do rodzajów konstrukcji dawnych młynów i ich jakości, źródeł pozyskiwania i nabywania kamieni młyńskich oraz poziomu życia młynarzy, widzianego przez pryzmat kultury materialnej. Zagadnieniem wartym uwagi są również trwałe przekształcenia krajobrazu kulturowego — powstałe w związku z infrastrukturą młynów liczne groble, kanały i rozległe niekiedy stawy ${ }^{1}$.

Analizę tak ujętego zjawiska gospodarczego, ale też kulturowego, przeprowadzono na przykładzie losów jednego z młynów we wsi Bystrzyca w pobliżu miasteczka Wleń, na południowym zachodzie Dolnego Śląska (ryc. 1). Badania oparto na metodach i źródłach kilku dyscyplin, głównie archeologii, historii i geografii, sumowanych w obrębie subdyscypliny określanej jako archeologia historyczna. Na bazę źródłową złożyły się lokalne przekazy pisane, archiwalia kartograficzne oraz wyniki podjętych w 2019 r. badań wykopaliskowych wraz z prospekcją nieinwazyjną.

Studia nad dawnym młynarstwem wodnym prowadzone są w Europie i na świecie, a dotyczą różnorodnych wątków badawczych. Zaliczają się do nich nie tylko zmiany w technologii samych urządzeń, lecz również studia krajobrazowe lub nad życiem codziennym młynarzy i ich rodzin. Wśród badaczy zajmujących się tematem są historycy, analizujący uwarunkowania prawne lokowania młynów, aspekty techniczne lub stosunki własnościowe ${ }^{2}$, geografowie, badający wpływ dawnego młynarstwa na przekształcenia krajobrazowe i sieć wodną ${ }^{3}$ języko-

1 Sochacka S. 2015; Fajer M., Waga J.M. 2017, s. 117-139.

2 Łuczak C. 1950; Samsonowicz H. 1954, s. 118-49; Trawkowski S. 1959; Podwińska Z. 1970; Reynolds T.S. 1983; Kouschil C. 2000; Myśliwski G. 2003; Kizik E. 2008; Sowina U. 2009, s. 56-62; Kubicki R. 2012, s. 276-287; Związek T. 2014, s. 118.

${ }^{3}$ Downward S., Skinner K. 2005; Krajniak W. 2016; Fajer M., Waga J.M. 2017; Brykała D., Podgórski Z. 2020. 


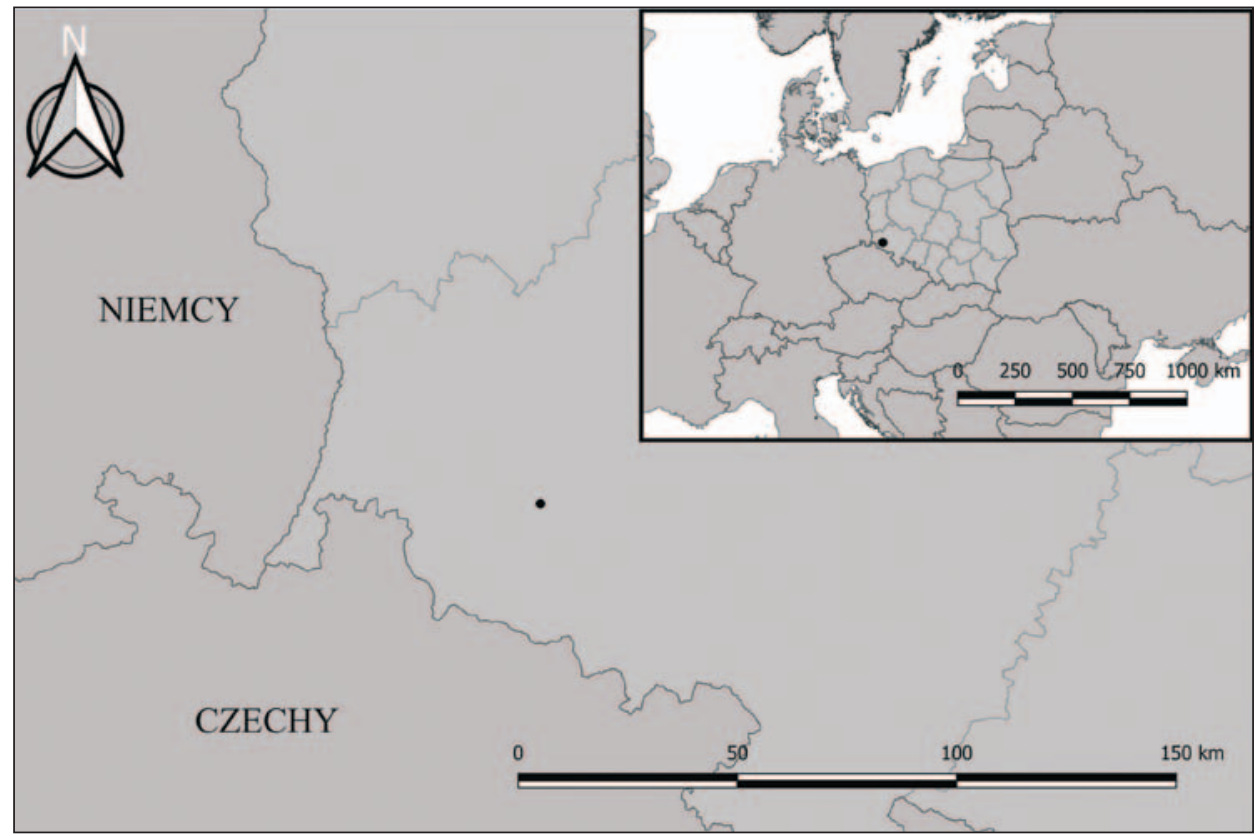

Ryc. 1. Lokalizacja wsi Bystrzyca (oprac. P. Duma)

Fig. 1. The location of Bystrzyca (prepared by P. Duma)

znawcy ${ }^{4}$, a także etnografowie ${ }^{5}$. Wczesne zainteresowanie badaniami dawnych młynów notuje się wśród archeologów z Wielkiej Brytanii ${ }^{6}$ i Francji ${ }^{7}$, gdzie wykopaliskowo rozpoznano wiele dobrze zachowanych pozostałości z różnych okresów. W ostatnich latach na gruncie archeologii europejskiej powstały cenne prace syntetyczne omawiające stań badań nad dawnym młynarstwem w szeroko pojętej Europie Środkowej ${ }^{8}$. Niektórzy z badaczy wyodrębniają tę interdyscyplinarną dziedzinę określając ją mianem molinologii lub w węższym ujęciu — archeologii molinologicznej ${ }^{9}$. Od dawna młynarstwo leży też w zasięgu zainteresowania archeologów przemysłowych ${ }^{10}$.

Aktualny stan wiedzy jasno wskazuje, że forma nowożytnych młynów europejskich była efektem ewolucji i udoskonaleń prowadzonych przez wiele stuleci. Konstrukcje tego rodzaju były znane w świecie śródziemnomorskim przynajmniej od ostatniego wieku p.n.e. ${ }^{11}$, chociaż na podstawie badań archeologicznych niektórzy są skłonni przesunąć tę granicę nawet na III w. p.n.e. ${ }^{12}$. Upadek Cesarstwa Rzymskiego nie zahamował upowszechniania się młynów, a w kolejnych wiekach napęd kołem wodnym przeszedł liczne modernizacje. Powstawały zatem urządzenia mające zastosowanie w rozmaitych dziedzinach — młyny służące do kruszenia rudy,

${ }^{4}$ Wiśniewski J. 1970; Choroś M., Jarczak Ł. 2015; Sochacka S. 2015.

${ }^{5}$ Wesołowska H. 1969.

${ }^{6}$ Bedwin O. 1980.

7 Leveau P. 1996; Champagne F. i in. 1997; Jaccottey L., Labeaune R. 2010.

${ }^{8}$ Galusová L. 2011; Galusová L. 2015; Berthold J. 2015; Jeute G. 2015.

${ }^{9}$ Archäomolinologie, zob.: Berthold J. 2016.

${ }_{10}$ Raistrick A. 1972, s. 114-117; Gordon R.B., Malone P.M. 1997, s. 237-241; Palmer M., Nevell M., Sissons M. 2012, s. 84-91.

${ }^{11}$ Holt R. 1988, s. 5-16.

${ }^{12}$ Rzepkowski K. 2015, s. 49. 
spilśniania tkanin, tartaczne, papiernicze i kuźniczne. Siła wody była używana powszechnie w wielu innych celach ${ }^{13}$. W czasach poprzedzających nowożytność stosowano dwa główne typy młynów wodnych: z kołem w pozycji horyzontalnej i wertykalnej. Ten pierwszy wariant, prosty, określany mianem „młynów greckich”, rozprzestrzenił się z Azji przez Europę Środkową i Północną do Irlandii i Szkocji1" ${ }^{14}$, lecz na Śląsku, jak się wydaje, nie występował. Młyny z kołem w układzie pionowym wymagające przekładni, określane mianem rzymskich lub witruwiańskich ${ }^{15}$, budowano głównie w najbardziej sfeudalizowanych częściach Europy, jak północna Francja i Niemcy. W zależności od tego, czy koło napędzała woda lejąca się na nie z góry, czy płynąca spodem, dzieli się je na podsiębierne lub nasiębierne. W rzadkich przypadkach, gdy siła wody skierowana była na połowę wysokości koła, są one określane mianem kół śródsiębiernych. Młyny z pionowymi kołami wodnymi pojawiły się w XII w. w Europie Środkowo-Wschodniej, w tym także w Polsce ${ }^{16}$. O pierwszych młynach na rzece Bóbr płynącej przez Dolny Śląsk, a więc region, który nas szczególnie zajmuje, wzmiankują źródła pochodzące z początku XIII w. w kontekście akcji osadniczej prowadzonej przez księcia Henryka Brodatego ${ }^{17}$.

Budowa młynów wodnych następowała na Śląsku szybko w kolejnych stuleciach. W XIV w. we wsiach należących do biskupstwa wrocławskiego znajdowało się ich 177, co daje średnio jeden młyn na półtorej wsi. Przypuszczalnie początkowo dominowały młyny z kołem podsiębiernym. Przy tego rodzaju konstrukcji nie były konieczne dodatkowe groble służące do spiętrzania wody, dosyć trudne do wykonania na terenach nizinnych ${ }^{18}$, lecz zdarzało się, że i tam budowane. Z czasem na nizinach zaczęły przeważać młyny wietrzne. Na terenach górskich i podgórskich, gdzie więcej było miejsc dogodnych do założenia młynów wodnych, w mniejszej liczbie stawiano wiatraki. Poza tym silniejsze wiatry mogły prowadzić do ich zniszczenia. Na Śląsku w 1787 r. wiatraki stanowiły już 34\% ze wszystkich 5152 młynów ${ }^{19}$. Przeważały one jednak w północnych, nizinnych strefach tego regionu. Na przykład w powiecie górowskim stanowiły 69\% młynów, w wołowskim 69\%, średzkim 67\%, zaś w podgórskich powiatach jeleniogórskim i nyskim - poniżej 5\% ${ }^{20}$. Młyny w większości lokalizowane były na terenach wiejskich. W 1787 r. jedynie 334 znajdowały się w granicach miast (w tym 122 wiatraki), stanowiąc 6,7\% ogólnej liczby młynów na Śląsku²1.

Wzrostowi liczby młynów towarzyszyło udoskonalanie ich konstrukcji. Znane we Francji od V w. młyny o kołach nasiębiernych, na Śląsku zaczęto stosować w wieku XIII ${ }^{22}$. Ich upowszechnienie w Europie Środkowo-Wschodniej nastąpiło jednak dopiero od schyłku XV do XVII w. ${ }^{23}$ Jak utrzymuje większość autorów, moc kół podsiębiernych (walnych) mogła być blisko dwu- lub nawet trzykrotnie mniejsza od nasiębiernych (korzecznych) ${ }^{24}$. Upowszechnianie wiedzy dotyczącej nowych rozwiązań było możliwe dzięki drukowanym podręcznikom i poradnikom skierowanym do młynarzy i rzemieślników budujących nowe młyny ${ }^{25}$. Jednakże, w przypadku głównie niepiśmiennych odbiorców, ich zasięg był ograniczony do wąskiego kręgu specjalistów.

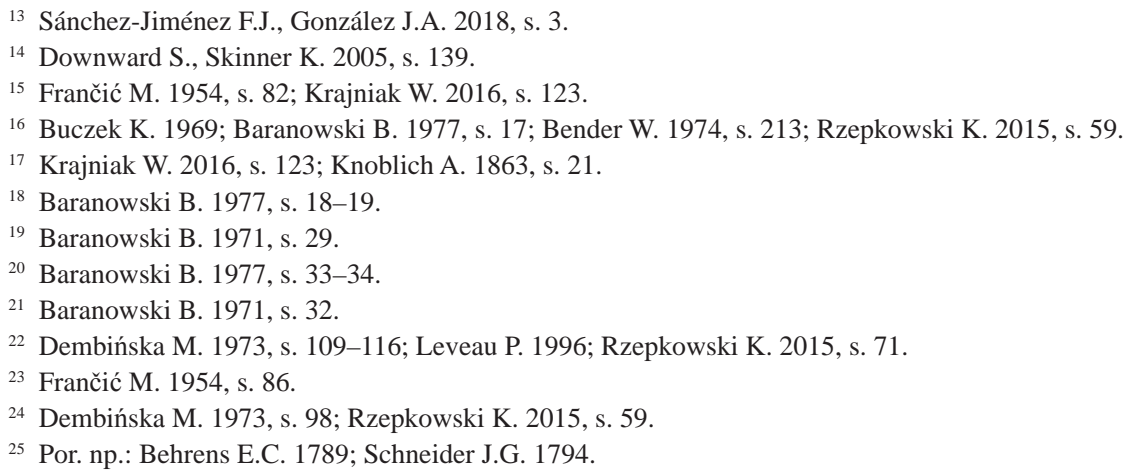


W literaturze przedmiotu dyskutowane są możliwości przerobowe młynów wodnych w różnych okresach. Zaznaczyć należy, że większość danych, na podstawie których prowadzone są wyliczenia, pochodzi z czasów nowożytnych. Różne są także założenia dotyczące łącznej liczby dni w roku, gdy młyn pracował. Dla nowożytności przyjmuje się, że wartość ta mieściła się w przedziale 125-150 dni. Zakłada się, że w XVI w. przerób dzienny wynosił 90 kg, co przy 125 dniach roboczych mogłoby dać wartość 108 ton rocznie. Z danych statystycznych z $1786 \mathrm{r}$. ze Śląska wiadomo, że jeden młyn przerabiał ok. 90 ton zboża rocznie ${ }^{26}$. Z tych samych danych statystycznych wynika także, że w młynie wodnym o standardowej konstrukcji na przełomie XVIII i XIX w. na mąkę przerabiano dziennie 120 kg zboża. W zależności od liczby dni pracy w ciągu roku dawało to sumę roczną wynoszącą od 150 do 180 ton. Wprowadzenie lepszych kamieni i udoskonalenie szczegółów technicznych konstrukcji w drugiej połowie XIX w. zapewne przyczyniło się do zwiększenia tej wartości ${ }^{27}$.

W przeciwieństwie do licznych informacji pozyskanych ze źródeł pisanych i etnograficznych dotyczących Europy Środkowo-Wschodniej, w tym Śląska, baza danych archeologicznych odnoszących się do młynów wodnych jest skromna. Obejmuje ona głównie relikty średniowieczne, a nie nowożytne, bardziej istotne dla podjętych w artykule kwestii. Nie ma również informacji o badaniach dawnych wiatraków. Na marginesie warto wspomnieć, że te z pozoru trudne do zweryfikowania metodami archeologicznymi konstrukcje są z powodzeniem badane w innych rejonach Europy ${ }^{28}$. Na Śląsku pozostałości młynów rejestrowano już w okresie międzywojennym, m.in. w Moczydlnicy Klasztornej i Oławie-Baumgarten. W tej ostatniej miejscowości odkryto także pozostałości młynów nowożytnych. W samej Moczydlnicy Klasztornej nie potwierdzono jednak istnienia budynku młyna, a jedynie drewniane koryto oraz pionowe pale w trudnych do zinterpretowania układach ${ }^{29}$.

Na młyny pochodzące ze schyłku średniowiecza natrafiono m.in. na Mazowszu, w Otalążce i Nasielsku. W miejscowości Otalążka były to relikty umocnionego nadbrzeża młynówki, drewniane pale oraz nieliczne ociosane elementy drewniane, które mogły wchodzić w skład konstrukcji młyna, głównie jednak zostały użyte do wykonania grobli. Datowanie tych obiektów na XIII-XIV w. określono na podstawie cech ostrogi i rozbitego naczynia ceramicznego odnalezionych na dnie młynówki ${ }^{30}$. Z kolei w Nasielsku odkryto dobrze zachowane pale drewniane z pomostu przy młynie wodnym oraz liczne zabytki ruchome (w tym fragment kamienia młyńskiego). Analiza dendrochronologiczna pozyskanego drewna wykazała, że konstrukcję wzniesiono w XV w. Odkrywcy nie wykluczają jednak, że na miejscu wcześniejszego założenia3 ${ }^{31}$. Stosunkowo dobrze zachowane relikty młyna wodnego odsłonięto też w Mniszku na Pomorzu Gdańskim. Zarejestrowano tam m.in. elementy drewnianych pozostałości koła wodnego i fragmenty kamienia młyńskiego z piaskowca. Analiza dendrochronologiczna wykazała, że drzewa na pale konstrukcyjne zostały ścięte ok. 1380 r., natomiast wieniec koła wodnego wykonany został na przełomie 1421 i 1422 r. Liczne fragmenty ceramiki i pozostałe zabytki ruchome świadczyły o długim okresie użytkowania konstrukcji, po okres nowożytny ${ }^{32}$. Dobrze zachowane pozostałości drewnianego młyna rozpoznano również w Ptakowicach, w powiecie brzeskim na Dolnym Śląsku³ ${ }^{33}$ którego użytkowanie trwało od końca XIII w. do zniszczenia przez pożar

${ }^{26}$ Baranowski B. 1971, s. 34.

27 Dembińska M. 1973, s. 182-191.

${ }^{28}$ Notebaart J.C. 1972; Crossley D. 1994, s. 127-137; Orser Ch.E. 2002; Rynne C. 2007, s. 246-249.

29 Fokt K. 2012, s. 188-190.

30 Bender W. 1974.

31 Błoński M., Żukowski R. 2019.

32 Górzyńska A., Górzyński T., Majewski M. 2011.

33 Bagniewski Z., Kubów P. 1977. 
w XV w. Krzysztof Fokt identyfikuje go z młynem poświadczonym przekazem pisanym z 1405 r. ${ }^{34}$ Natomiast na fragment nowożytnego kompleksu młyńskiego natrafiono w Raduszynie w Wielkopolsce. Zdaniem badaczy założenie funkcjonowało w XVI-XVII w. ${ }^{35}$

Przebadano również relikty młyna wodnego leżącego koło wsi Szkotkowo na Pojezierzu Chełmińsko-Dobrzyńskim. Dobrze zachowały się tam elementy drewniane pochodzące z budynku i umocnienia nadbrzeża. Znaleziska monet i ceramiki, jak również daty dendrochronologiczne (1710-1726) wskazują, że młyn działał w stuleciach XVIII i XIX. Na wtórnym złożu odnaleziono także ceramikę średniowieczną, sugerującą istnienie w tym rejonie starszego mły$\mathrm{na}^{36}$. To jedne $\mathrm{z}$ nielicznych młynów pochodzących z okresu nowożytnego przebadanych w granicach Polski.

Młyny funkcjonowały w ściśle wytyczonych ramach prawnych, te zaś przeszły wraz z nastaniem epoki industrialnej głębokie i istotne przeobrażenia. Już w 1714 r. w młynach funkcjonujących w dobrach należących do śląskiej arystokratycznej rodziny Schaffgotschów zmieniono zasady krótkoterminowej dzierżawy młynów, zezwalając na ich wykupywanie ${ }^{37}$. Następnie w 1772 r. władze pruskie zniosły monopol dworu na budowę nowych młynów, chociaż — jak wskazują informacje z majątków Schaffgotschów — już wcześniej zdarzało się, że młyny stawiano bez zgody pana lub uruchamiano dodatkowe koła, nie zgłaszając tego dworowi ${ }^{38}$. W $1810 \mathrm{r}$. zlikwidowano natomiast przymus mlewa, zaś w połowie XIX w. czynsze młyńskie. Również od 1772 r. istniał jednolity podatek przemysłowy, który wynosił 12 talarów od jednego złożenia kamieni. Zasada wolności przemysłowej umożliwiała stawianie nowych młynów na własnych gruntach. Według przepisów z 1810 r. konstrukcje te nie podlegały w ogóle oczynszowaniu, a właściciele płacili jedynie podatek przemysłowy. Znacznie bardziej obciążeni byli młynarze posiadający młyny starsze, często będące własnością ich rodzin od pokoleń. Prócz płacenia wysokich podatków byli oni też zobligowani do innych powinności, które ostatecznie zlikwidowano dopiero w roku $1850^{39}$. Odpowiednie regulacje wprowadzane przez państwo pruskie w prowincji śląskiej odnosiły się również do kwestii utrzymania infrastruktury młyńskiej, częstotliwości czyszczenia młynówek i zaleceń dotyczących jakości stawianych młynów wodnych ${ }^{40}$.

W XIX w. sytuacja prawna i daleko idące usprawnienia techniczne doprowadziły do kryzysu tradycyjnego młynarstwa. Zauważalny jest proces masowej likwidacji małych młynów i intensywna modernizacja pozostałych. Powstawały młyny duże, których wydajność była znacznie większa od tradycyjnych konstrukcji, a od czwartej ćwierci XIX w. także elektrownie wodne, częściowo wykorzystujące starą infrastrukturę i mające znaczny wpływ na przekształcenia cieków wodnych. Niektóre z młynów zbożowych traciły swoje pierwotne funkcje i stawały się papierniami ${ }^{41}$. Dodatkowo, na skutek rozbudowy kolei i taniego transportu węgla wzrosło znaczenie maszyn parowych, które wygrywały konkurencję z niskowydajnymi mechanizmami napędzanymi kołem wodnym. Nie zrezygnowano jednak z użycia siły wody, a wynalezienie turbiny wodnej przyniosło dalsze zmiany ${ }^{42}$. Najważniejszą z nich było wprowadzenie dużych, zmechanizowanych młynów, a pierwszy tego typu obiekt powstał w 1785 r. w Ameryce Północnej. W podobnym czasie postawiono również młyn parowy w Londynie. Anglicy udoskonalili silnik parowy, który powszechnie zaczęto stosować w młynach na całym świecie.

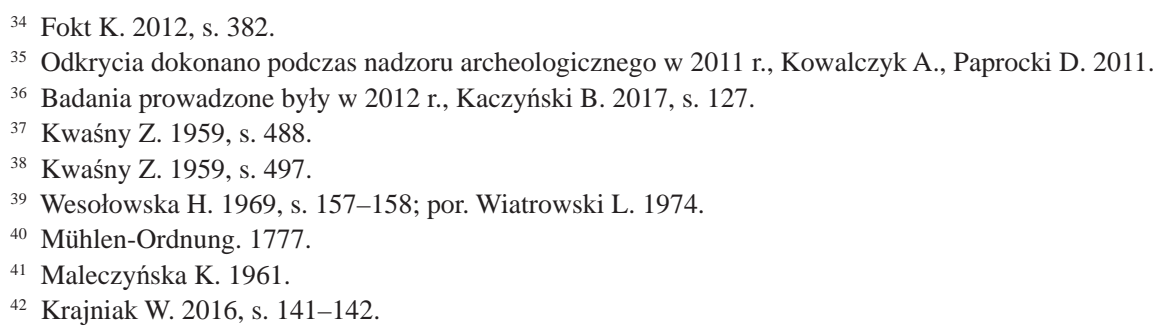


Co ciekawe, pierwsze młyny londyńskie zostały wkrótce po wybudowaniu zniszczone przez tłum mieszkańców przestraszonych szybkością tempa zachodzących zmian ${ }^{43}$. Na Dolnym Śląsku pierwszy taki młyn miał powstał w $1816 \mathrm{r}$. w Wałbrzychu, jako jeden z pierwszych w ówczesnych Niemczech $^{44}$. W 1834 r. podobny zbudowano w Oławie ${ }^{45}$. Przyczyny spadku liczby młynów wodnych nie leżały jedynie w postępującej modernizacji napędu. Powszechne stało się używanie walców stalowych do przemiału zboża, co prawda znanych od XVI w., ale wtedy jeszcze mocno niedoskonałych ${ }^{46}$ i stosowanych raczej do mielenia gipsu lub kory. Pierwsze próby z użyciem walców stalowych do mielenia zboża prowadzono w 1820 r., a ich konstrukcje były udoskonalane praktycznie przez cały wiek XIX. Wprowadzono również walce porcelanowe ${ }^{47}$.

Efektem tych zmian było upowszechnienie się przemysłowego sposobu przemiału zboża do końca XIX w. Obliczano, że w latach osiemdziesiątych tegoż stulecia roczna zdolność przemiałowa 10 zmechanizowanych młynów wrocławskich wynosiła ok. 1000000 ton, podczas gdy w 2557 małych młynach, w których nie wprowadzono większych modernizacji, osiągała łącznie ok. 1278500 ton. Różnica była zatem kolosalna, a młyny zmechanizowane typu amerykańskiego mogły przerabiać zboże praktycznie bez przerwy i bez względu na pogodę, okresowy brak wody i inne czynniki naturalne. Dzięki zastosowaniu nowoczesnych maszyn jakość mąki była o wiele lepsza niż w tradycyjnych młynach, a przerób zboża tańszy. Młyny te miały również dodatkowe zalety w postaci własnego transportu, wyspecjalizowanego personelu i strategii pozyskiwania nowych klientów wśród chłopów i piekarzy. Drobni młynarze próbowali walczyć z konkurencją, udoskonalając własne zakłady. Jednakże koszty modernizacji mogli ponieść jedynie najzamożniejsi z nich, posiadający oprócz młynów również gospodarstwa o wielkości przekraczającej przynajmniej 25 ha $^{48}$. Do wiejskich młynarzy docierali wyspecjalizowani agenci oferujący nowe maszyny młynarskie, produkowane w wielu zakładach zlokalizowanych we Wrocławiu, Brzegu, Nysie i Szczecinie ${ }^{49}$. Zarazem konsekwentnie prowadzona regulacja wielu rzek i strumieni, a także prace melioracyjne i drenowanie pól doprowadziły do zmniejszenia się poziomu wód. Brak wody w strumieniu przez większość roku powodował spadek opłacalności użytkowania młyna i w konsekwencji jego likwidację ${ }^{50}$. Jednakże sam proces nieuchronnego zaniku małych młynów wodnych nie postępował tak szybko, jakby to wynikało wprost z tempa modernizacji i upowszechniania się dużych młynów mechanicznych. Wydaje się, że przyczyną opóźnienia tego zjawiska mogło być przywiązanie do wypracowanych przez wieki zachowań wśród tradycyjnej społeczności wiejskiej, problemy transportowe i odległość od większych młynów ${ }^{51}$. Z usług mniejszych młynów wodnych korzystali więc chłopi ubożsi i osoby uważające, że chleb z mąki zmielonej w takim młynie jest zdrowszy od upieczonego z mąki zmielonej w młynie mechanicznym. Metal w ich przekonaniu miał pozbawiać ziarno istotnych własności odżywczych. Ponadto klienci młynów często żądali mąki uzyskanej z ich własnego ziarna. Natomiast tylko w małych młynach możliwe było dokonanie małego zasypu, rzędu 50-100 kg². W dużych młynach ziarno stawało się anonimowe.

Proces wprowadzania turbiny wodnej, która zaczęła zastępować koło wodne, nasilił się na progu XX w. Oblicza się, że stopień wykorzystania siły wody przy tradycyjnym kole wynosił

${ }^{43}$ Mosse J. 1967, s. 53; Bartyś J. 1970, s. 164-169; Rzepkowski K. 2015, s. 102-104.

${ }^{44}$ Feldhaus F.M. 1914, s. 723.

45 Bartyś J. 1970, s. 175.

${ }^{46}$ Frančić M. 1954, s. 94.

47 Bartyś J. 1970, s. 138-145.

${ }^{48}$ Wesołowska H. 1969, s. 96-98.

49 Wesołowska H. 1969, s. 107.

${ }^{50}$ Baranowski B. 1977, s. 73.

${ }^{51}$ Wesołowska H. 1969, s. 99.

${ }^{52}$ Wesołowska H. 1969, s. 130-131. 
35-70\%, podczas gdy w przypadku turbiny wartość ta wynosiła 60-90\%. Szacunki dla Górnego Śląska wskazują, że w okresie międzywojennym przeciętna moc koła wodnego dochodziła do 5,04 KM, podczas gdy turbina wodna dawała średnio aż $32 \mathrm{KM}$. I choć modernizacja starych młynów została w tym czasie zintensyfikowana, nie uchroniło to wszystkich urządzeń przed likwidacją ${ }^{53}$. Ponadto, mimo systematycznie wzrastającej liczby ludności, zwiększona wydajność nowych urządzeń młyńskich w pełni zaspokajała zapotrzebowanie na przerób zboża na mąkę.

Nie ma bezpośrednich danych pozwalających na zrekonstruowanie liczby młynów w poszczególnych okresach dla Śląska, jednakże na podstawie spisów podatkowych i późniejszych danych statystycznych możliwe jest przybliżone ich ustalenie. Wiadomo, że we wsiach śląskich w 1577 r. żyło łącznie 1390 młynarzy; w przybliżeniu mogło się to przekładać na liczbę młynów (wodnych i wiatrowych). W 1787 r. młynów było łącznie 5152. Zatem, według ówczesnego stanu ludności, jeden młyn przypadał średnio na 8 km² i obsługiwał 340 mieszkańców ${ }^{54}$. W $1818 \mathrm{r}$. notowano jeszcze 5929 młynów, podczas gdy w 1907 r. było ich już tylko 3033. Jak się szacuje, na obszarze Śląska jeden młyn w 1849 r. przypadał przeciętnie na 512 mieszkańców, podczas gdy w 1907 r. już na 1606 osób ${ }^{55}$.

Tytułowy młyn w Bystrzycy leży w południowo-zachodniej części Dolnego Śląska, na północnej krawędzi Gór Kaczawskich, przechodzących tam w Pogórze Kaczawskie. Obserwacje układu zarówno współczesnej, jak i historycznej sieci rzecznej (przedstawionej w źródłach kartograficznych) oraz form terenu związanych z procesami fluwialnymi pozwalają wnioskować, że sieć hydrograficzna na tym obszarze w nowożytności, podobnie jak obecnie, odznaczała się dużą gęstością i rozbudowanym układem cieków wodnych różnej wielkości. Regulacje hydrotechniczne prowadzone od początku XX w. nie zmieniły jej w znacznym stopniu.

Dużą dostępność do zasobów wodnych oraz energii wodnej na analizowanym terenie należy uznać za czynnik sprzyjający rozwojowi osadnictwa i działalności gospodarczej. Zwłaszcza cieki górskie o dużych spadkach umożliwiały funkcjonowanie urządzeń wykorzystujących koło wodne. Z drugiej strony, rzeki te charakteryzują się dużą zmiennością przepływów, co jest czynnikiem utrudniającym użycie naturalnej siły wody, wymagającym budowy infrastruktury w postaci kanałów, stawów i grobli.

Precyzyjnych informacji o usytuowaniu młynów wodnych w naturalnych warunkach zachodnich Sudetów dostarczyły dane lotniczego skanowania laserowego (ALS). Wykorzystano w tym celu pomiary pozyskane w ramach programu ISOK ${ }^{56}$ i włączone do repozytorium Państwowego Zasobu Geodezyjnego i Kartograficznego (dalej cyt.: PZGiK). Dane dystrybuowane w postaci wstępnie klasyfikowanych chmur punktów poddano reklasyfikacjii ${ }^{57}$ i wizualizacji stosując serię algorytmów pozwalających uwidocznić słabo czytelne elementy topografiiis8. Efektem tych prac były zobrazowania kilku założeń młyńskich, uzupełnione o warstwy interpretacyjne wykreślające przebieg grobli, domniemany zasięg zbiorników wodnych i lokalizację pozostałości zabudowy. Wstępne obserwacje zrewidowano w terenie wiosną 2019 r., odkrywając wiele pozostałości dawnych młynów wodnych, grobli oraz stawów w różnym stopniu zachowania (ryc. 2). Jeden z nich, młyn Dolny w Bystrzycy koło miasteczka Wleń, wybrano do szczegółowych badań archiwalnych i wykopaliskowych (ryc. 3).

Zasilany był on wodą z potoku o współczesnej nazwie Wierzbnik ${ }^{59}$. Dolina tego cieku w większości nawiązuje do równoleżnikowego przebiegu Rowu Wlenia, stanowiącego połu-

53 Wesołowska H. 1969, s. 78.

54 Baranowski B. 1971, s. 24.

55 Baranowski B. 1977, s. 71-73.

56 Wężyk P. 2015.

57 Kiarszys G., Szalast G. 2014.

58 Bennett R. i in. 2012; Hesse R. 2013.

59 W literaturze podaje się, że potok przed 1945 r. był bezimienny, w rzeczywistości nazywał się Würfelbach, zob.: Baumert D. 2017, s. 8. 


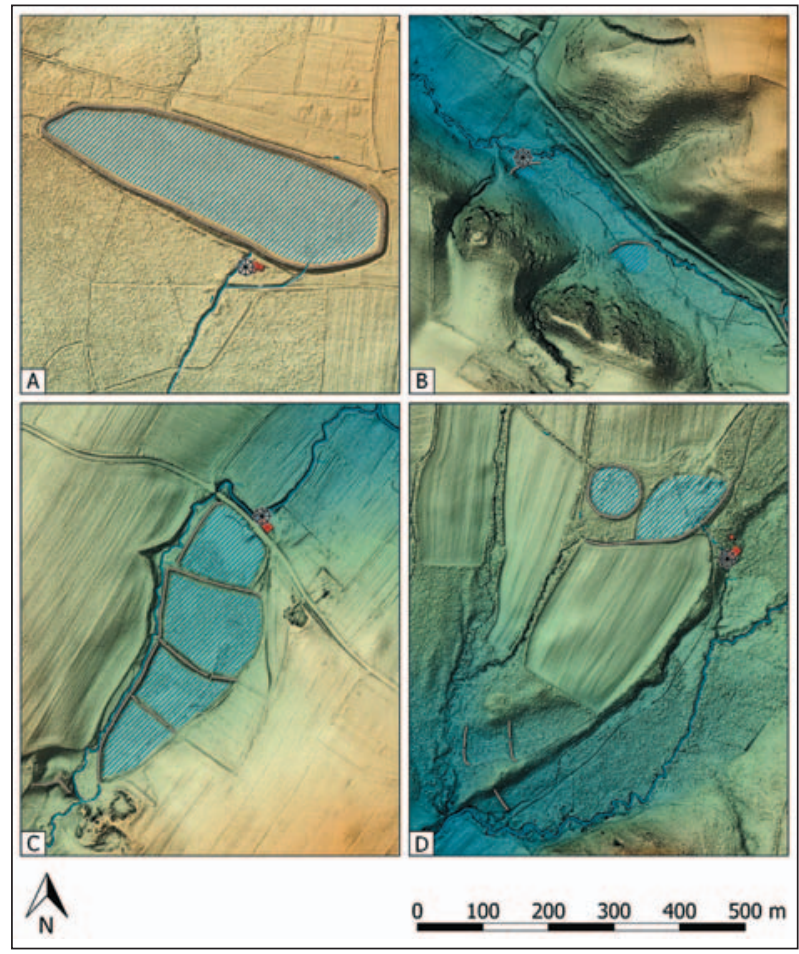

Ryc. 2. Schematy założeń młyńskich w zachodnich Sudetach na podkładzie przedstawiającym ukształtowanie terenu: A - Młyńsko, pow. lwówecki; B - Modrzewie, pow. lwówecki; C - Milęcice, pow. lwówecki; D - Dziwiszów, pow. jeleniogórski (oprac. M. Mackiewicz)

Fig. 2. A schematic representation of mills in the Western Sudetes against landform features: A - Młyńsko, district of Lwówek Śląski; B - Modrzewie, district of Lwówek Śląski; $\mathrm{C}$ - Milęcice, district of Lwówek Ślaski; D - Dziwiszów, district of Jelenia Góra (prepared by M. Mackiewicz)

dniową część Pogórza Kaczawskiego. Jest on prawobrzeżnym dopływem Bobru i tworzy zlewnię III rzędu według A.N. Strahlera ${ }^{60}$. Jego obszar źródliskowy znajduje się na terenie górskim, na północnych stokach Babińca, na wysokości ok. 420 m n.p.m., natomiast strefa ujścia do Bobru położona jest na wysokości ok. 235 m n.p.m. Blisko dwustumetrowa różnica wysokości, przy długości cieku zaledwie $6,36 \mathrm{~km}$, daje jego duży spadek (0,03, czyli blisko $\left.2^{\circ}\right)$, a tym samym duży potencjał energetyczny, co było istotnym czynnikiem lokalizacji młynów wodnych. Położenie młyna zabezpiecza go przed falą powodziową Bobru. Różnica poziomów pomiędzy młynem a ujściem Wierzbnika do Bobru wynosi ok. 20 m, a zatem nawet rekordowe wezbranie Bobru, które podniosłoby też poziom tzw. cofek jego dopływów (czyli wlewanie się wody wezbranego Bobru do koryt i dolin jego dopływów), nie zniszczyłoby budynku i urządzeń młyńskich. Sam Wierzbnik jest rzeką na tyle krótką (6,36km), że raczej nie mógł, nawet przy relatywnie dużym wezbraniu, osiągnąć poziomu zagrażającego młynowi, usytuowanemu nie nad samą rzeką, lecz nieco wyżej (różnica poziomów ok. 2-3 m) i zasilanemu młynówką.

Wieś Bystrzyca (niem. Wiesenthal) położona na wschód od miasta Wleń (niem. Lähn) ma średniowieczną metrykę. W literaturze podaje się, że pierwsza znana data dotycząca miejscowości zapisana została w 1217 r. jako Biztrichtzt. Obecnie jednak przeważa pogląd, że informacja ta odnosi się do innej miejscowości, natomiast pierwsza faktyczna wzmianka o wsi pochodzi dopiero z roku 1319, a następnie z 1372 (Wiesenthal, Wessental) ${ }^{61}$. Była to wieś

60 Strahler A.N. 1957.

61 Uzasadnione wątpliwości co do identyfikacji wsi Bystrzyca (Wiesenthal) z wymienioną 1217 r. parafialną wsią Bistrichtz (SUB. 1971, nr 164) przedstawił Heinrich Appelt (Appelt H. 1939), a następnie Benedykt Zientara (Zientara B. 2006, s. 157). Obaj Autorzy są zdania, że wymieniona w 1217 r. nazwa Bistrichtz to pobliski Nowy Kościół, obecnie w powiecie złotoryjskim, zob. też: Rospond S. 1968, s. 133. 


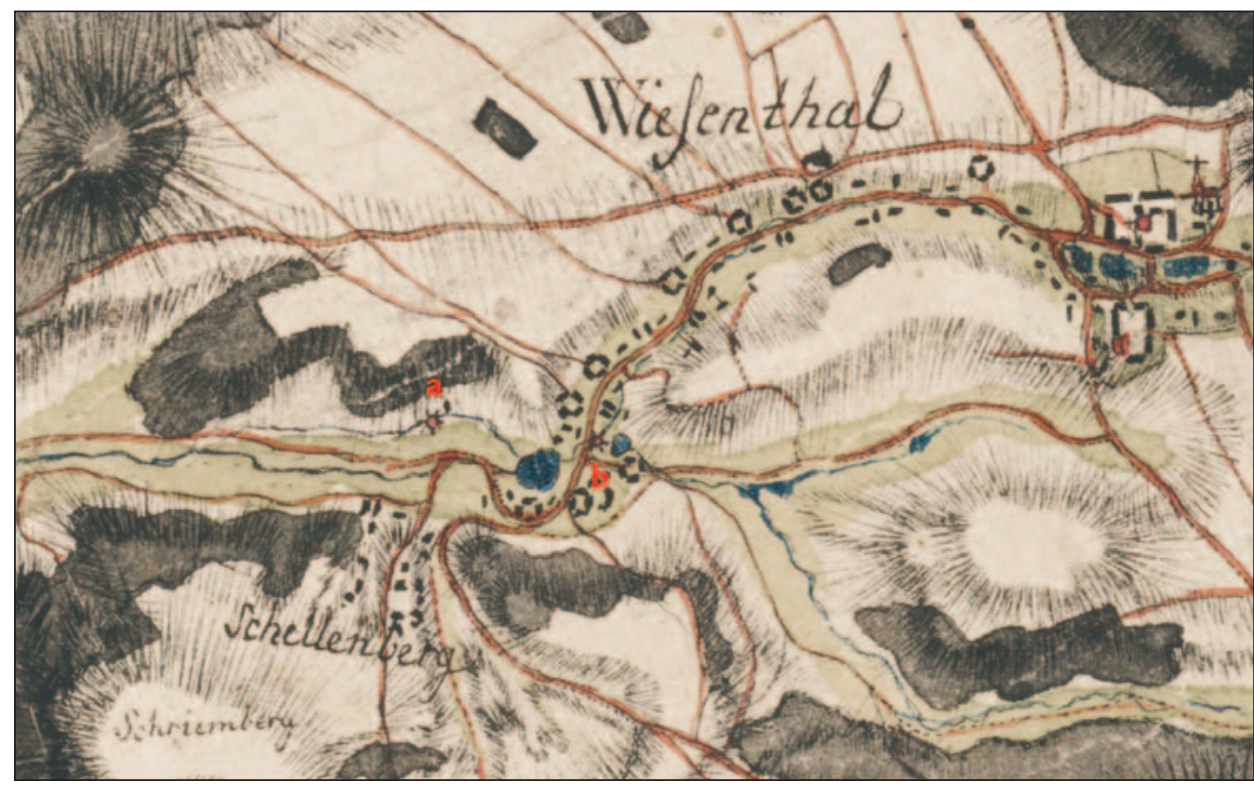

Ryc. 3. Lokalizacja młynów wodnych we wsi Bystrzyca na mapie Śląska L.W. Reglera z 1764-1770, ze zbiorów Staatsbibliothek zu Berlin: a — Młyn Dolny; b — Młyn Górny (według: Regler L.W. 1764-1770, SBB IIIC Kart N 15140 Blatt 43; oprac. P. Duma)

Fig. 3. The location of mills in Bystrzyca on L.W. Regler's map of Silesia from 1764-1770, from the collection of Staatsbibliothek zu Berlin: a - the Lower Mill; b - the Upper Mill (after: Regler L.W. 1764-1770, SBB IIIC Kart N 15140 Blatt 43; prepared by P. Duma)

leśno-łanowa wytyczona i zasiedlona w toku kolonizacji niemieckiej. Potrzeby mieszkańców w zakresie przetwórstwa zboża zaspokajały w czasach nowożytnych dwa młyny wodne oraz wiatrak. Ten ostatni został zlicytowany i rozebrany przed rokiem 1906. Na podstawie analizy źródeł kartograficznych wiadomo, że oba młyny wodne funkcjonowały przynajmniej od XVIII w. Młyn Dolny (Niedermühle) położony był kilkaset metrów przed właściwymi zabudowaniami wsi, od strony zachodniej, pod archiwalnym nr 69 (ryc. 4). Przylegał od strony południowej do skarpy wyniesienia określanego jako Mühlberg (332 m n.p.m.) — obecnie Gościradka. Młyn Górny, o nr 67 (Obermühle), zlokalizowany był pośród zabudowań mieszkalnych w zachodniej części wsi62 ${ }^{62}$ Odległość między młynami nie była znaczna i wynosiła ok. 450 m w linii prostej. Młyn Górny korzystał bezpośrednio z wody rzeki Wierzbnik płynącej przez wieś. Do Młyna Dolnego prowadziła młynówka zasilająca staw młyński, a dalej biegnąca wzdłuż stoku do budynku z kołem. Czytelna do dzisiaj szerokość młynówki wynosiła maksymalnie 1,5-2 m. Nie jest znany pierwotny przekrój suchego obecnie koryta. Jednak ze względu na wysokość skarpy i rekonstruowaną lokalizację koła wodnego można przypuszczać, że przy ujściu z młynówki woda była kierowana drewnianym korytem zawieszonym bezpośrednio nad kołem. Trudno jednak wnioskować na temat pierwotnej długości drewnianej rynny. Mierząc wysokość bezwzględną młynówki od miejsca opuszczenia grobli przy stawie, do stoku wyniesienia i odcinka znajdującego się za budynkiem młyna widoczny jest wyraźny spadek (kolejno: 268,2 — 267,7 — 261 m n.p.m.), który wynosi łącznie 7,2 m. Sam budynek młyna leży na wysokości ok. 263,5 m n.p.m. (ryc. 4).

62 Baumert D. 2017, s. 8. 


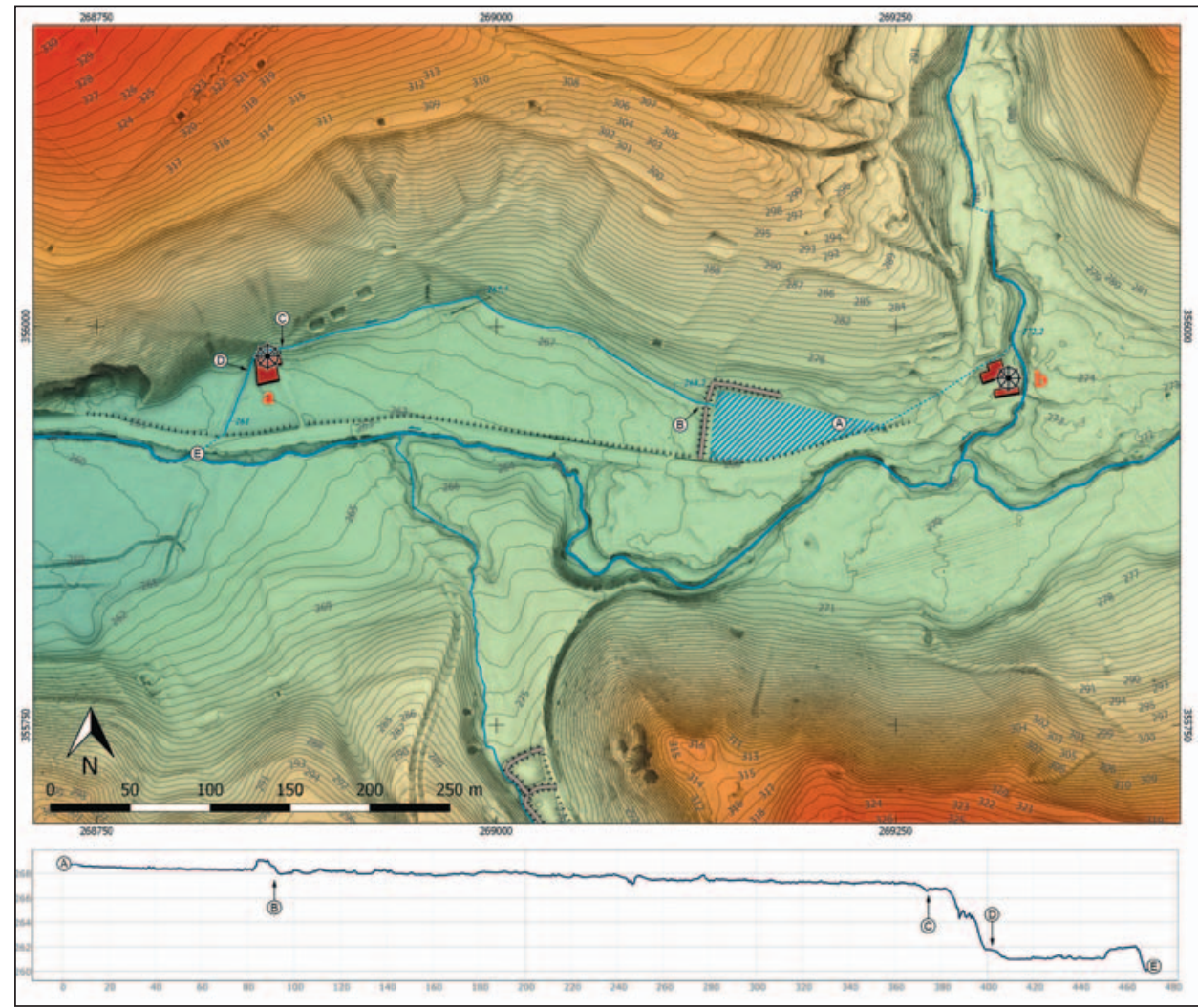

Ryc. 4. Bystrzyca. Lokalizacja reliktów młynów wraz z rekonstrukcją stawu młyńskiego i młynówki na mapie hipsometrycznej:

a — Młyn Dolny; b — Młyn Górny (oprac. M. Mackiewicz)

Fig. 4. Bystrzyca. The location of the relics of the mill, with a reconstruction of the mill pond and the stream powering the mill, on a hypsometric map:

$\mathrm{a}$ — the Lower Mill; b — the Upper Mill (prepared by M. Mackiewicz)

Pierwsze pewne informacje o właścicielach Młyna Dolnego pochodzą z XIX w. W 1837 r. został on sprzedany i wtedy przypuszczalnie trafił w ręce rodziny Firl. O późniejszych losach właścicieli wiadomo pośrednio dzięki zachowanym aktom uwłaszczeniowym i umowie z lipca 1855 r. Młyn Dolny był wówczas w posiadaniu owdowiałej Johanny Firl, z domu Scholz (ur. w 1818 r.), która po śmierci męża Wilhelma (ur. w Bystrzycy w 1818 r.) wyszła ponownie za mąż za karczmarza — Augusta Andersa. Johanna i Wilhelm mieli dwóch synów — Gustava Emila Firla (ur. w 1843 r.) oraz Friedricha Augusta; obaj w dokumencie z 1855 r. określani byli jako niepełnoletni. Co prawda właściciele młyna zyskali na zniesieniu powinności feudalnych, lecz również inni mieszkańcy wsi zwolnieni zostali z powodów młyńskich, tj. robocizny, w ramach której wykonywali regularne naprawy grobli, młynówki i stawu ${ }^{63}$. Rodzina musiała w kolejnych latach popaść w finansowe kłopoty, ponieważ 28 lipca 1863 r. władze powiatowe ogłosiły publiczną licytację mebli, bielizny pościelowej i ubrań znajdujących się w młynie, a należących do rodziny Firl. Aukcja miała odbyć się o godzinie 9 rano 11 sierpnia. Powodem

${ }^{63}$ Ablösung der Mühldienste. 1855. 
miały być niespłacone należności ${ }^{64}$. Można przypuszczać, że młyn także przeszedł na własność państwa. O jego losach w kolejnych latach, aż do schyłku XIX w. niewiele wiadomo. Przypuszczalnie młyn znalazł nowego właściciela, który uruchomił przemiał zboża i poczynił pewne inwestycje, jednak z czasem musiał zbankrutować, ponieważ władze miasta Wlenia 3 lutego 1896 r. wystosowały pytanie do Krajowego Urzędu Kultury Rolnej we Wrocławiu (Landeskulturamt Breslau) z prośbą o podanie ewentualnych powinności związanych z Młynem Dolnym w związku z jego przymusową licytacją. Pojawił się nowy młynarz wyrażający chęć zakupu nieruchomości ${ }^{65}$, jednak z niepublikowanej rękopiśmiennej kroniki Bystrzycy spisanej przez Ernsta Siebenhaara ${ }^{66}$ wiadomo, że Młyn Dolny został zakupiony w 1897 r. nie przez młynarza, lecz przez kupca, Heinricha Schindlera. Pozbył się on w tym samym czasie mechanizmu młyńskiego, a dawny staw młyński przekształcono w łąkę. Budynek w kolejnych latach przeszedł w ręce właściciela majątku w Dolnej Bystrzycy, Hermanna Feige, zamieszkałego pod archiwalnym nr 68 i pozostał jego własnością aż do czasu zniszczenia.

Jak informowała ówczesna lokalna prasa, 7 grudnia 1910 r., krótko przed północą, zauważono pożar w byłym młynie ${ }^{67}$. Budynek był wówczas niezamieszkany i przeznaczony od dłuższego czasu do rozbiórki. Ponieważ pokrycie wykonane było zapewne z materiałów łatwopalnych (przypuszczalnie gontów), pożar bardzo szybko się rozprzestrzenił i opanował całą konstrukcję, która spłonęła. W gaszeniu ognia nie pomogły przybyłe na miejsce zastępy straży z Bystrzycy i okolicznych wsi. Podejrzewano przy tym umyślne podpalenie obiektu, ponieważ tej samej nocy około godziny pierwszej stanął też w płomieniach budynek gospodarczy połączony z domem mieszkalnym należący do stolarza Gerlacha, w pobliskiej wsi Łupki (niem. Schiefer). Jego przebieg był równie gwałtowny. Wiadomości te wskazują, że młyn stał pusty od dawna, zaś wyniki badań archeologicznych wykazały, że budynek nie był modernizowany i prawdopodobnie nigdy nie doprowadzono do niego elektryczności. Pozostało w nim jednak wiele przedmiotów i zużytych sprzętów, które odkryto podczas wykopalisk.

Pozostałości młyna w Bystrzycy zostały wytypowane do badań archeologicznych na podstawie przeprowadzonej wcześniej prospekcji terenowej ${ }^{68}$. W jej toku autorzy badań zweryfikowali wiele miejscowości z reliktami młynów wodnych, ujętych na archiwalnych mapach autorstwa Ludwika Reglera z lat $1764-1770^{69}$ oraz Urmesstischblatt z pierwszej połowy XIX w. ${ }^{70}$ Istotne było też nietypowe położenie oraz stosunkowo dobry stan zachowania Młyna Dolnego. Celem prac terenowych było rozpoznanie planu założenia, a także odnalezienie i rekonstrukcja ewentualnych starszych reliktów, pozwalających na prześledzenie wcześniejszych rozwiązań technicznych związanych z dostarczaniem wody na koło oraz przemiałem zboża. Badania podjęte w 2019 r. objęły niemal całą powierzchnię istniejących reliktów (ok. 145 m²), lecz głównie polegały na odsłonięciu i rozpoznaniu przebiegu murów. Wykonano jeden wykop badawczy (w narożu północno-wschodnim odsłoniętego budynku), szerzej omówiony w dalszej części artykułu. Nigdzie jednak nie osiągnięto warstwy calcowej.

Omawiany młyn reprezentuje powszechny w przeszłości typ konstrukcji, w której pod jednym dachem znajdował się budynek mieszkalny razem z pomieszczeniem produkcyjnym. Niemal wszystkie ściany budynku, obecnie miejscami zachowane maksymalnie do wysokości

${ }^{64}$ Auktion. 1863.

65 Ablösung der Mühldienste. 1855, s. 34.

66 Siebenhaar E. 1906.

67 Feuer. 1910.

68 Badania są częścią prowadzonego w Instytucie Archeologii Uniwersytetu Wrocławskiego programu „Krajobraz kulturowy zachodnich Sudetów”, zob. m.in.: Chorowska M. i in. 2017; Duma P. i in. 2020; Duma P., Łuczak A., Piekalski J. 2019.

69 Regler L.W. 1764-1770.

${ }^{70}$ Urmesstischblätter. 1823-1824. 


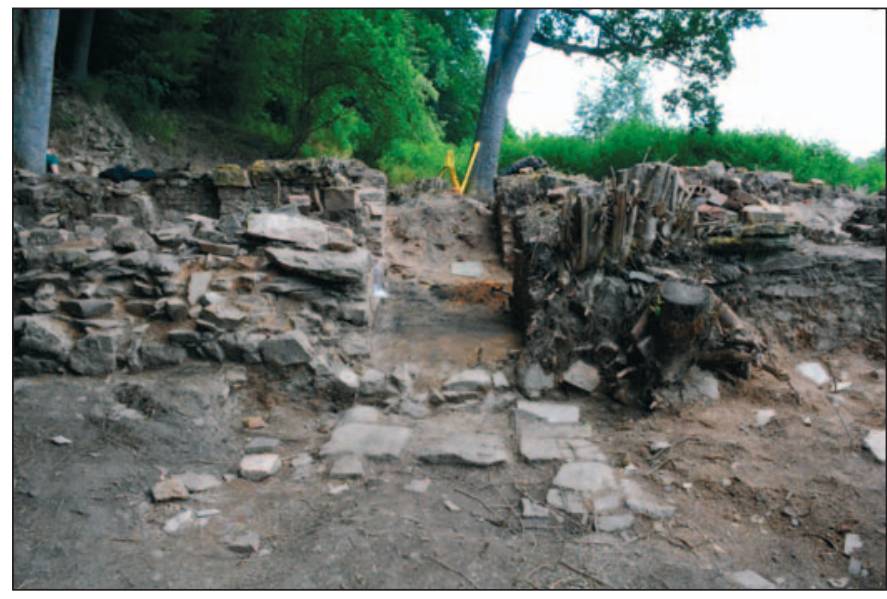

Ryc. 5. Bystrzyca, odsłonięte relikty Młyna Dolnego. Widok od strony południowo-zachodniej (fot. P. Duma)

Fig. 5. Bystrzyca, the uncovered relicts of the Lower Mill, viewed from the south-west (photo by P. Duma)

1,2 m, wykonano z kamienia łamanego — miejscowego bazaltu, rzadziej z szarego piaskowca (ryc. 5). Detale architektoniczne zrobiono natomiast z czerwonego piaskowca. Fragmenty wtórnie użytych i rozbitych kamieni młyńskich tkwiące w niektórych partiach pozostałych ścian świadczą, że budynek w trakcie swego istnienia był przebudowywany.

Nie zachowały się plany młyna, jednak dzięki przeprowadzonym pracom archeologicznym udało się odtworzyć układ pomieszczeń oraz sprecyzować funkcję większości z nich (ryc. 6). Odsłonięte pozostałości młyna były zbliżone w rzucie do prostokąta o wymiarach ok. 19×11 m, dłuższą osią orientowanego po linii północ-południe (ryc. 7). Znajdujący się na środku korytarz (oznaczony nr 5), dzielił bryłę budynku na dwie zasadnicze części: mieszkalną od strony południowej i produkcyjną od północnej. Nie wiadomo jednak, czy w podobny sposób zagospodarowane były wyższe kondygnacje. Na ich istnienie wskazują znaleziska z gruzu zalegającego w pomieszczeniach. Część produkcyjna składała się z pomieszczenia głównego (oznaczonego podczas badań nr 3), z przyległej do niego od północy konstrukcji kamiennej (nr 1), w której pierwotnie umieszczone było koło wodne, oraz pomieszczenia zapewne magazynowego (oznaczonego nr 2) od zachodu. Korytarz, stanowiący oś budynku, przebiegający po linii wschód-zachód, miał szerokość 1,15 m. W jego zachodnim odcinku (przebadanym na długości 2,5 m) stwierdzono podłogę w formie klepiska. Odkryty w zasypisku rząd ręcznie formowanych cegieł sugerował, że korytarz pierwotnie przykryty był sklepieniem.

Część mieszkalna, do której wchodziło się z korytarza (zarówno od zachodu, jak i od wschodu), podzielona była w partii przyziemia na trzy wnętrza ogrzewane jednym urządzeniem zlokalizowanym pośrodku. Z zachodniego odcinka korytarza prowadziło wejście (o szerokości $1,14 \mathrm{~m}$ ) do pomieszczenia ( $\mathrm{nr}$ 6) o wymiarach wewnętrznych 3,05 ×2,30 m, połączonego z kolejnym pomieszczeniem ( $\mathrm{nr}$ 7) osobnym przejściem (o szerokości 0,91 m). Drzwi zamocowano tam w drewnianej futrynie (z belek o przekroju $14 \times 16 \mathrm{~cm}$ ). Ściana oddzielająca oba pomieszczenia miała grubość 0,72 m. Jej część wschodnia (przechodząca do pomieszczenia nr 8) była zbudowana z cegieł i miała przebieg skośny. Można przypuszczać, że to relikt komina bądź urządzenia grzewczego umieszczonego na styku trzech wnętrz (nr 6, 7, 8). Pomieszczenie nr 7 miało wymiary wewnętrzne 2,90 (w kierunku północ-południe) × 3,38 m. Oba te wnętrza były doświetlane oknami od strony zachodniej. Otwór okienny w pomieszczeniu nr 6 zlokalizowano w odległości 1,07 m od narożnika północno-zachodniego. W dolnej partii jego szerokość zewnętrzna wynosiła $0,62 \mathrm{~m}$, zaś wewnętrzna $0,82 \mathrm{~m}$, czyli był rozglifiony do wnętrza. Na parapecie zalegały fragmenty okiennego szkła taflowego, ciętego romboidalnie. Z kolei w pomieszczeniu nr 7 otwór okienny mieścił się w odległości ok. 0,95 m od jego narożnika 


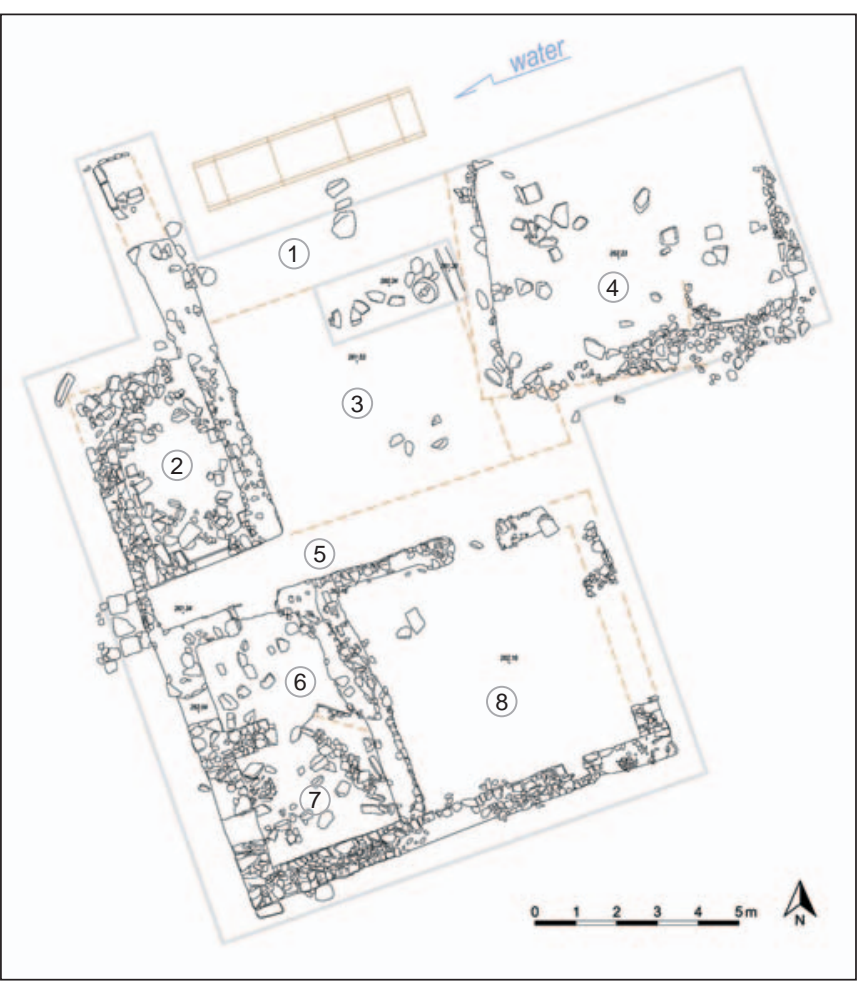

Ryc. 6. Bystrzyca, plan odkrytych reliktów z oznaczeniem numerów pomieszczeń i przypuszczalną lokalizacją koła wodnego (oprac. M. Mackiewicz)

Fig. 6. Bystrzyca, a plan of the uncovered relics, with the rooms numbered and the probable location of the water wheel marked (prepared

by M. Mackiewicz)

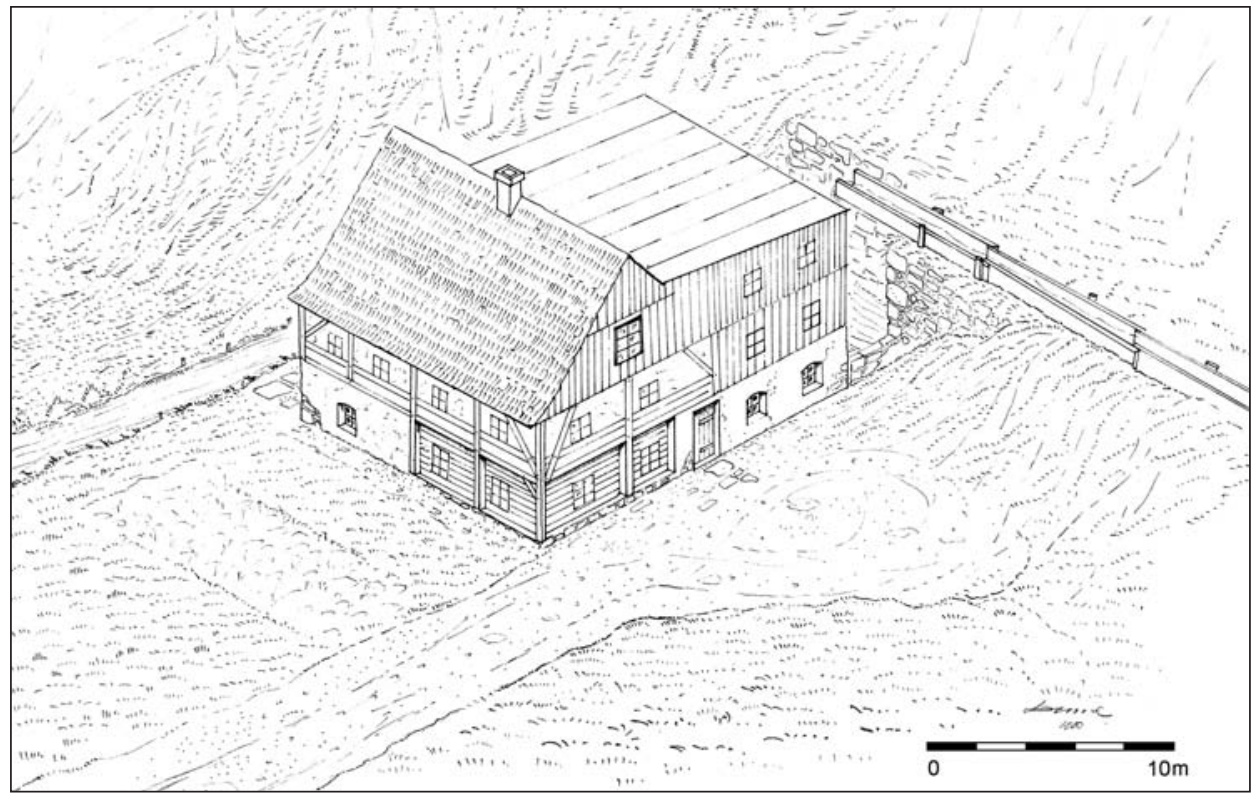

Ryc. 7. Bystrzyca. Rysunkowa rekonstrukcja budynku Młyna Dolnego (rys. P. Duma)

Fig. 7. Bystrzyca. A reconstruction of the Lower Mill (drawn by P. Duma) 
południowo-zachodniego i miał szerokość 0,60 m. Na parapecie również odkryto potłuczone szyby. Grubość ściany zewnętrznej tych wnętrz wahała się od 0,66 do 0,84 m. Nie udało się rozpoznać konstrukcji podłóg. W gruzowisku znaleziono liczne kafle piecowe z drugiej połowy XIX w. Ich rozmieszczenie wskazywało, że musiały one pochodzić z pieca stojącego na wyższej kondygnacji.

Z opisanymi pomieszczeniami od strony wschodniej sąsiadowała izba (nr 8) o wymiarach 5,6 (w kierunku wschód-zachód) × 5,7 m (północ-południe), dostępna ze wschodniej części korytarza przez otwór drzwiowy (o szerokości 1,06 m). Jej ściany południowa i wschodnia były prawdopodobnie z drewna (w konstrukcji zrębowej?), posadowione na kamiennej podmurówce, którą odkryto podczas badań. Tylko w tym pomieszczeniu nie było gruzu kamienno-ceglanego, co dodatkowo wzmacnia przypuszczenie o zastosowanym pierwotnie materiale budowlanym. W podmurówce ściany południowej (o grubości 0,71 m) odsłonięto zarys wnęki, być może podokiennej. Wnętrze przykryte było podłogą z desek. Prawdopodobnie, analogicznie do innych domów z tego czasu, występujących w regionie, w izbie tej mógł się znajdować stół z ławami w narożniku południowo-wschodnim oraz piec kuchenny przy ścianie zachodniej; nie zostało to jednak potwierdzone archeologicznie ${ }^{71}$. Długość ściany zachodniej (wewnętrznej) wynosiła tylko 2,6 m, po czym skośnie przechodziła do pomieszczenia nr 6/7. Przypuszczalnie miało to związek z urządzeniem grzewczym, którego szczegóły konstrukcyjne nie zostały rozpoznane podczas zrealizowanych prac.

Północna, produkcyjna część budynku podzielona była na dwa, wyraźnie odseparowane pomieszczenia (oznaczone nr 2 i 3) oraz dostawioną do skarpy, zabezpieczoną murem oporowym strefę techniczną (nr 1). Ta ostatnia miała plan zbliżony do prostokąta o wymiarach 6,2 (po linii wschód-zachód) × 4,7 m (północ-południe). To tu zamontowane było koło młyńskie. Młynówka płynęła stokiem od strony północnej i prawdopodobnie za pomocą drewnianej rynny skierowana była na koło nasiębierne. Poprowadzenie młynówki w tym miejscu gwarantowało uzyskanie odpowiedniej siły wody, ale spowodowało konieczność znacznego podcięcia naturalnej skarpy i zbudowanie muru oporowego (częściowo do dziś zachowanego). Woda po spadku z koła (ustawionego w linii wschód-zachód) przepływała przez niski mur kamienny i opływała budynek kierując się w stronę południowo-zachodnią, tworząc czytelne w terenie koryto o maksymalnej szerokości 2,35 m, obecnie suche.

Koło wodne przenosiło prawdopodobnie za pomocą wału siłę napędową na urządzenia młyńskie znajdujące się w przyległym od południa pomieszczeniu nr 3. Miało ono plan prostokąta o wymiarach 5,9 (w kierunku wschód-zachód) × 5,4 m (północ-południe), o grubości ścian 0,55-0,65 m. W ścianie wschodniej stwierdzono odsadzkę (o szerokości 0,26 m), na której przypuszczalnie opierała się drewniana podłoga.

Kolejne pomieszczenie ( $\mathrm{nr}$ 2) było nieogrzewane, a więc zapewne miało przeznaczenie gospodarcze (magazynowe?). Sąsiadowało od zachodu z zasadniczym dla funkcji młyna pomieszczeniem nr 3 i miało powierzchnię 2,55 (wschód-zachód) × ok. 3,35 m (północ-południe). Dostępne było z zachodniego odcinka korytarza otworem drzwiowym (o szerokości 0,87 m) z prostym portalem z czerwonego piaskowca. Zachował się jeden żelazny zawias świadczący, że drzwi te otwierały się do wnętrza. Wewnątrz tego pomieszczenia, przy progu, w warstwie spalenizny odnaleziono klucz z piórem.

Podczas prac archeologicznych prowadzonych w Bystrzycy zarejestrowano jeszcze jedną konstrukcję, młodszą od budynku młyna (oznaczoną nr 4). Jej ściana zachodnia nachodziła na pozostałości wschodniej ściany młyna w obrębie pomieszczenia nr 3. Zasięg tej budowli rozpoznano wstępnie; określono jej wymiary, które w rzucie poziomym wynosiły 7,3 (w kierunku wschód-zachód) × ok. 4,5 m (północ-południe). Dobrze zachowane narożniki północno-zachod-

${ }^{71}$ Peuckert W.E. 1928; Härtel H. 1941; Loewe L. 1969. 
nie i fragment ściany północnej wskazują, że zbudowano je głównie z niestarannie ułożonego piaskowca, o niedokładnie obrobionych krawędziach oraz ze zlepieńców i pojedynczych cegieł. Przebieg reliktów muru zachodniego nie pokrywał się z przebiegiem muru wschodniego pomieszczenia nr 3. Oba fundamenty wyraźnie różniły się techniką wykonania, zastosowanymi materiałami i trwałością. Wnioskować z tego można, że mur ten, podobnie jak cały budynek, powstał po spaleniu młyna w 1910 r. Brak gruzu we wnętrzu oraz odnalezione na powierzchni zabytki wskazują, że po pożarze wystawiono w tym miejscu niewielki budynek gospodarczy wykonany w partii naziemnej z drewna. Od strony północnej przylegał on bezpośrednio do skarpy. Jest świadectwem użytkowania tego terenu po zaprzestaniu działalności i upadku młyna.

Zabytkami, które jednoznacznie wskazywały na funkcję całego opisywanego założenia, były kamienie młyńskie znalezione w pomieszczeniu 3. Odkryto tam zachowany w całości biegun z piaskowca oraz elementy koła zmontowanego z segmentów wykutych z kwarcytu francuskiego. Poza tym, w innych częściach młyna znaleziono kilkanaście fragmentów zużytych kamieni młyńskich z drobnoziarnistego piaskowca.

Od jakości surowca i poprawnego wykonania kamieni zależała też jakość uzyskiwanej mąki i czas przemiału zboża, a więc skuteczność działania młyna. Cechy tych elementów pośrednio odzwierciedlają globalne zmiany, jakie zaszły w zakresie przetwórstwa zbożowego w XIX w. i ukazują bardzo szeroką sieć powiązań, która ukształtowała się w epoce industrialnej, a związana była z rozwojem dalekosiężnego handlu i konsumpcji.

Zachowany w całości piaskowcowy kamień z pomieszczenia $\mathrm{nr} 3$ to biegun o średnicy $60 \mathrm{~cm}$ i średnicy oka $18 \mathrm{~cm}$, z wcięciem na żelazną paprzycę (ryc. 8). Jego powierzchnię pracującą pokrywa wzór skośnie krzyżujących się rowków; jest to uważane za technikę rozpowszechnioną w XVIII w. Miało to zapewnić bardziej kontrolowalny ruch mlewa do otworu zasypowego oraz chroniło go od tzw. palenia ${ }^{72}$. Z drugiego zestawu kamieni z kwarcytu francuskiego odkryto 15 elementów, o wymiarach: $45 \times 20 \mathrm{~cm}, 36 \times 25 \mathrm{~cm}, 46 \times 23 \mathrm{~cm}$ i podobnych ${ }^{73}$. Większość $z$ nich miała kształt trapezowaty. Niektóre były porowate, lecz, jak się wydaje, było to skutkiem wysokiej temperatury podczas pożaru. Kamienie z kwarcytu francuskiego uchodziły za drogie, a na Śląsku zaczęły być częściej używane dopiero w drugiej połowie XIX w. Wskazuje to na inwestycje, które poczyniono w tym czasie w obiekcie.

Warto zastanowić się nad kwestią wykorzystania w młynie w Bystrzycy

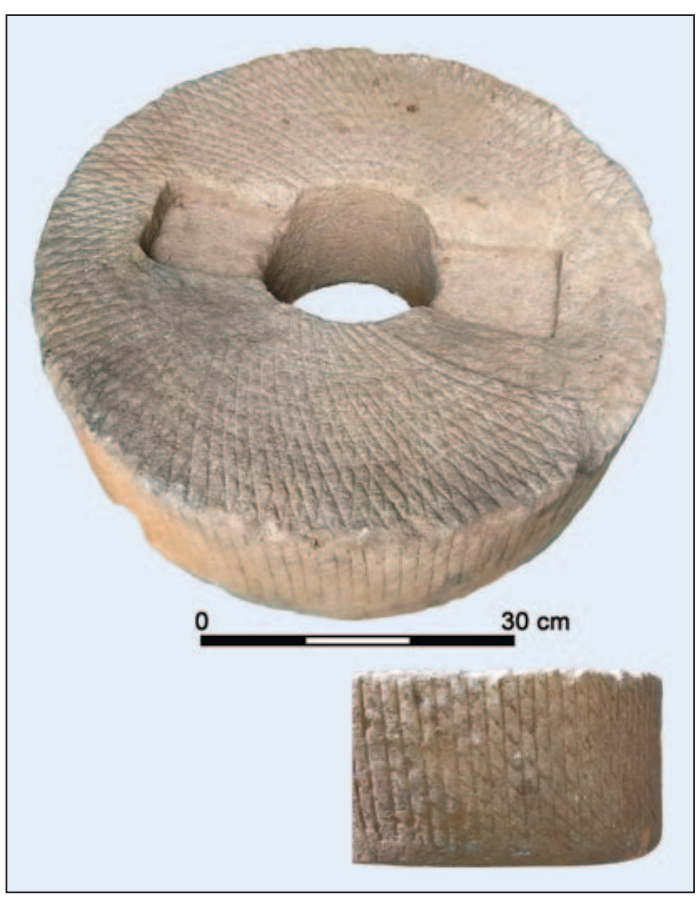

Ryc. 8. Bystrzyca, Młyn Dolny. kamień młyński z piaskowca (fot. N. Lenkow)

Fig. 8. Bystrzyca, the Lower Mill. A sandstone millstone (photo by N. Lenkow)

72 Baranowski B. 1977, s. 40.

73 Ponieważ nie wszystkie elementy zostały wydobyte z wykopu w pomieszczeniu 3 (część z nich tkwiła w profilach), nie udało się zrekonstruować całości kamieni i określić ich dokładnej średnicy. 
obu rodzajów kamieni młyńskich — wykonanych z tych dwóch różnych surowców ${ }^{74}$. Na Śląsku do ich wyrobu używano tradycyjnie piaskowca. Kamień ten dominował w zasadzie do połowy XIX w. Kwerenda map archiwalnych wskazuje, że kamieniołomy specjalizujące się głównie w produkcji kamieni młyńskich znajdowały się w wielu śląskich miejscowościach ${ }^{75}$. Temat ten w zakresie studiów regionalnych został już podjęty ${ }^{76}$, lecz nadal pozostaje wiele pytań wymagających wyjaśnienia. Wiadomo, że piaskowiec ze Śląska rozprowadzano daleko poza jego granice. Od XV w. kamienie te za pośrednictwem kupców toruńskich trafiały do młynów działających w Państwie Zakonu Krzyżackiego. Ich ceny były stosunkowo niskie w porównaniu z kamieniami nadreńskimi ${ }^{77}$. Na terenach Królestwa Polskiego takie kamienie młyńskie określano mianem „ślązaków”. Piaskowiec ze Śląska był ceniony ze względu na gruboziarnistość ${ }^{78}$. Mniej zamożni młynarze zaopatrywali się przeważnie w kamienie lokalnego pochodzenia ${ }^{79}$. Spora zmiana nastąpiła u schyłku XVIII w., gdy wprowadzono kamienie wykonywane z kwarcytu francuskiego. Surowiec ten był sprowadzany z kamieniołomu w La Ferté-sous-Jouarre we Francji ${ }^{80}$. Równocześnie piaskowiec był nadal używany do produkcji śruty ${ }^{81}$.

Kamienie francuskie wymieniane są pierwszy raz w połowie XIX w. w źródłach pochodzących z Opolszczyzny. Ich upowszechnienie nastąpiło w ostatnich dekadach tegoż stulecia. Można przypuszczać, że podobnie wyglądało to na Dolnym Śląsku. Kamienie te były twardsze i większe od wyrobów z piaskowca. Różnica w średnicy mogła wynosić nawet $30-50 \mathrm{~cm}^{82}$. Większe okazy składano ze starannie dobranych i przyciętych fragmentów. Potem spajano je wysokogatunkowym cementem lub żelazną obręczą. Pozwalało to na właściwe dobranie kamieni o jednakowej strukturze, twardości i porowatości, której nie spotyka się w większych bryłach. Powierzchnia takiego kamienia była wyrównywana przy użyciu specjalnych maszyn, a rowki nakuwano precyzyjnie ostrzami stalowymi lub diamentowymi. Dla mniej zamożnych nabywców sprowadzano kamienie w postaci bardzo małych brył kwarcytowych. Dopiero na miejscu je sortowano, spajano, szlifowano i nakuwano uzyskane z nich mlewniki ${ }^{83}$. Kamienie nakuwano w sposób określany jako system amerykańsko-prostolinijny, gdzie proste bruzdy biegły od środka kamienia ku jego brzegom pod kątem ostrym. Nazywały się one bruzdami głównymi. Pola cierne pomiędzy bruzdami określano kwaterami. System ten był powszechnie stosowany w drugiej połowie XIX w. ${ }^{84} \mathrm{Z}$ takim kamieniem mamy do czynienia w przypadku fragmentów odnalezionych w Bystrzycy (ryc. 9). Nakucia na powierzchni należało odnawiać dość często i robił to przeważnie sam młynarz. Częstotliwość nakuwania zależała zapewne od jakości surowca i intensywności przemiału. J. Bartyś podaje, że przy mieleniu suchej i oczyszczonej pszenicy nakuwanie należało powtarzać po tygodniu pracy, przy mieleniu żyta i wilgotnej pszenicy już co dwa, trzy dni ${ }^{85}$. Ziarna chwastów w zbożu mogły dodatkowo przyspieszać proces jego ścierania.

W Młynie Dolnym w Bystrzycy używano kamieni młyńskich obu rodzajów — tradycyjnych na Śląsku piaskowców i obcych na tym terenie, sprowadzanych z Francji kwarcytowych.

74 Pochodzenie i wartość kamieni młyńskich w Europie to zagadnienia mające sporą literaturę i grono specjalistów, por.: Seen through a millstone. 2014, tam liczne publikacje.

75 Wrede Ch.F. 1747-1753; Regler L.W. 1764-1770.

76 Lisowska E., Gunia P., Borowski M. 2014.

77 Kubicki R. 2012, s. 156-159.

78 Bartyś J. 1970, s. 103.

79 Samsonowicz H. 1954, s. 132.

80 Tucker G.D. 1982; Ward O.H. 1982.

81 Baranowski B. 1977, s. 80.

${ }^{82}$ Wesołowska H. 1969, s. 106.

83 Bartyś J. 1970, s. 106.

84 Bartyś J. 1970, s. 116.

85 Bartyś J. 1970, s. 117. 
Obecność tych drugich można interpretować jako próbę dostosowania urządzeń produkcyjnych do zmian zachodzących w XIX w. i przetrwania kryzysu młynów tradycyjnych. W przypadku młyna w Bystrzycy była to próba nieudana.

O stylu i warunkach życia mieszkańców tego obiektu świadczy w pewnej mierze dość skromna przestrzennie, mieszkalna część budynku. Można stwierdzić, że przeciętny wiejski dom mieszkalny obszaru sudeckiego w XVIII-XIX w. zapewniał lepszy komfort ${ }^{86}$. Istotnych danych o materialnych aspektach bytowania dostarczają pozyskane w trakcie wykopalisk znaleziska — łącznie 8520 sztuk. Najstarsza z odkrytych monet datowana jest na rok 1783, ale zdecydowana większość materiałów łączy się chronologicznie z ostatnimi dekadami użytkowania młyna. W gruzie odnaleziono też dwie pruskie monety: jedną o nominale 24 części talara z 1783 r., zaś drugą — 3 fenigi wybitą w $1830 \mathrm{r}$.

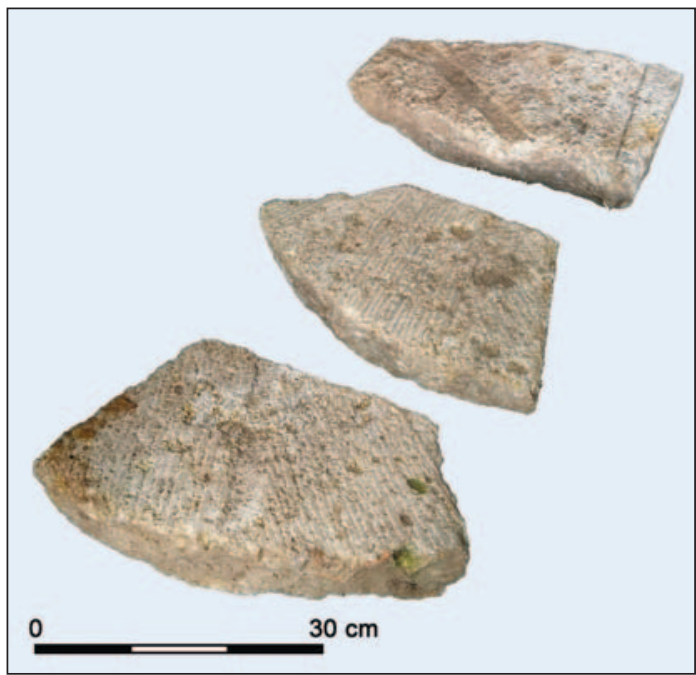

Ryc. 9. Bystrzyca, Młyn Dolny. Element koła młyńskiego z kwarcytu francuskiego (fot. N. Lenkow)

Fig. 9. Bystrzyca, the Lower Mill. A French quartzite millstone part (photo by N. Lenkow)

Najliczniejszymi zabytkami są fragmenty naczyń ceramicznych - 4181 sztuk (łącznie z kamionką — 49\% całości zbioru), poza tym z porcelany i fajansu (256 sztuk - 3\%), ułamki kafli piecowych (410 sztuk — 4,8\%), wyroby szklane (2076 egzemplarzy — 24\%), zróżnicowane funkcjonalnie przedmioty metalowe (1316 - 15\%), oraz kości zwierzęce (54 - 0,6\%). Zostały one wydobyte głównie z nawarstwień pożarowych i gruzu zalegającego w opisanych pomieszczeniach, lecz najwięcej podczas eksploracji wykopu badawczego założonego w narożu północno-wschodnim pomieszczenia nr $3^{87}$ (ryc. 6). Stwierdzono tam warstwę pożarową, w której znaleziono aż 2098 fragmentów ceramiki (czyli 24,6\% wszystkich pozyskanych). Dominowały wśród nich wyroby białe, szkliwione zarówno obustronnie, jak i tylko wewnątrz, głównie mniejsze i większe części naczyń różnej wielkości, w tym mis, kubków, rzadziej talerzy. Szkliwo przeważnie miało kolor brązowy i żółtawy (musztardowy). Rzadko notowano inne naczynia — kremowe, nieszkliwione i brunatne. Zabarwienie tych ostatnich było wynikiem wtórnego przepalenia, lecz pierwotnie prawdopodobnie także było jasne. Kilka fragmentów o barwie ceglastej to części zniszczonych doniczek. Prócz tego odnaleziono 176 ułamków (2\%) naczyń porcelanowych i fajansowych (ryc. 10), przede wszystkim filiżanek oraz talerzy i talerzyków. Wiele z nich pochodziło ze zdekompletowanych serwisów wykonanych pod koniec XIX w. przez firmę Villeroy \& Boch w Dreźnie. Wśród pozostałości naczyń fajansowych dominowały misy i części urynału.

Zabytków metalowych pozyskano tu łącznie 507 sztuk (5,9\%). Były to przeważnie gwoździe kute i wykonane maszynowo w różnych rozmiarach, a także śruby konstrukcyjne, fragmenty blach, wiader, garnków żeliwnych, uprzęży końskiej oraz sprężyny meblowe róż-

${ }^{86}$ Loewe L. 1969.

${ }^{87}$ Wymiary tego wykopu (stosunkowo niewielkie w porównaniu z powierzchnią całego pomieszczenia) wynosiły: 3,5 m (po linii wschód-zachód) × 1,5 m (północ-południe). Grubość eksplorowanych tu warstw osiągnęła ok. 2,10 m. 


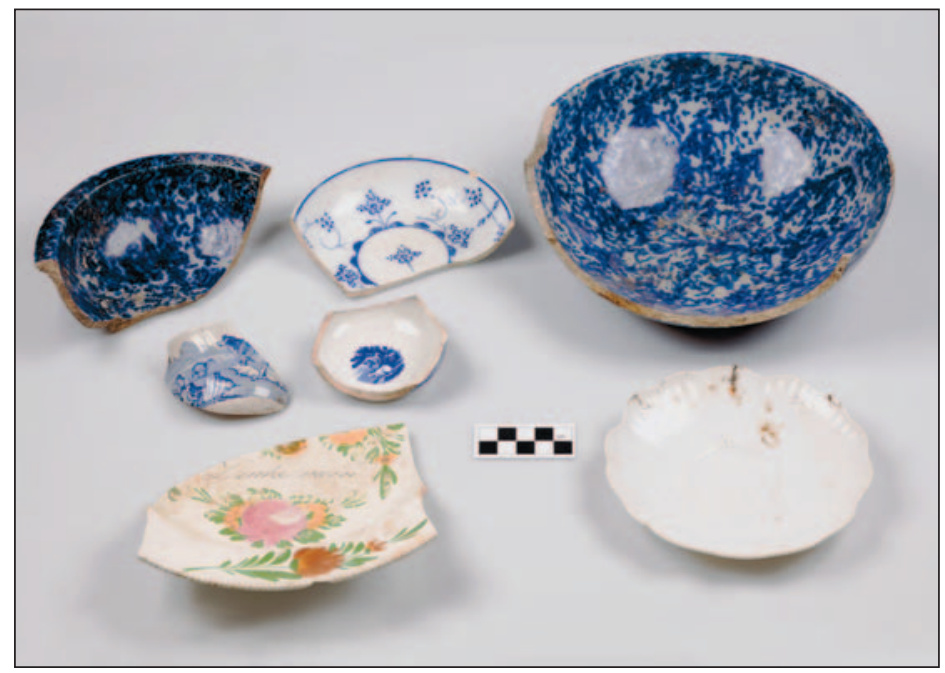

Ryc. 10. Bystrzyca, Młyn Dolny.

Fragmenty naczyń

fajansowych

i porcelanowych

z warstwy pożarowej

(fot. B. Miazga)

Fig. 10. Bystrzyca, the Lower Mill.

Fragments of faience and porcelain dishes from the fire layer (photo by B. Miazga)

Ryc. 11. Bystrzyca, Młyn Dolny.

Butelki szklane po medykamentach z warstwy pożarowej (fot. B. Miazga)

Fig. 11. Bystrzyca, the Lower Mill.

Empty medication bottles found in the fire layer (photo by B. Miazga)

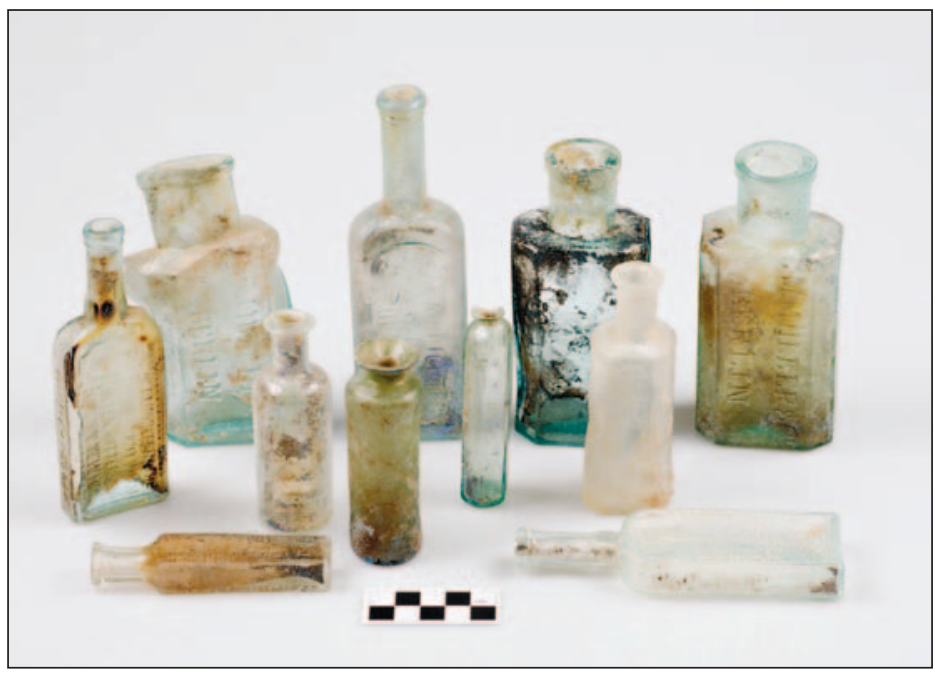

nej wielkości. Pozostałe przedmioty z metali odkryte w czasie badań to m.in. okulary, nożyczki, elementy mechanizmów lamp naftowych, jak również cała, niewielkich rozmiarów lampa wykonana z blachy. Inne znaleziska ruchome to: fragmenty porcelanowych fajek, pięć łupkowych rysików do pisania z tabliczką, trzy osełki, dwa fragmenty skóry oraz fragment zwęglonej tkaniny.

Wyroby ze szkła to ułamki szyb, jak również miseczki ze szkła prasowanego oraz klosze lamp naftowych, szklane guziki oraz fragmenty butelek różnej pojemności i o różnym przeznaczeniu, w tym 54 sygnowane. Te ostatnie miały wytłoczone na powierzchni napisy: „C.M. Müller \& Co, Berlin”, „Jaeger \& Kiesslich, Berlin S.O.”, „Anker-Pain-Expeller, F. AD. Richter \& Cie, Rudolstadt, Wien, Olten, Rotterdam, London, New York”, „Hienfong Essenz”, „Universal Balsam I. M. Grebehahn Reichmansdorf, No 35” (ryc. 11). Pierwotnie w pojemnikach tych znajdowały się rozmaite olejki i substancje uśmierzające ból, rzadziej inne produkty. Na przykład fabryka chemiczna „Jaeger \& Kiesslich” założona w 1896 r. produkowała środki do 
czyszczenia metali oraz pielęgnacji obuwia. Środki przeciwbólowe i olejki firmy „Anker” miały leczyć wiele schorzeń, przede wszystkim bóle reumatyczne. Płyn kryjący się pod handlową nazwą „Hienfong” miał zwalczać nerwobóle oraz dolegliwości żołądkowe. Był traktowany także jako uniwersalny środek na wiele innych przypadłości ${ }^{88}$. Podobne zastosowanie miał też balsam produkowany przez I.M. Grebehahn’a w Reichmannsdorf w Turyngii.

Z uwagi na sporą ilość odnalezionych opakowań szklanych po lekach można sądzić, że środki tego rodzaju, dostępne bez recepty, były dość często używane przez mieszkańca lub mieszkańców budynku. Lekarstwa mające uśmierzyć bóle reumatyczne mogą wskazywać, iż któryś z domowników cierpiał właśnie na takie schorzenie.

Wąskie datowanie pozyskanych zabytków, w tym butelki wyprodukowanej po roku 1896, wskazuje, że zbiór ten powstawał w dość krótkim czasie — ok. 10-15 lat do chwili pożaru w 1910 r. Można zatem domniemywać, że przedmioty te należały głównie do ostatniego właściciela nieruchomości, co świadczy, że po zakupie młyna i demontażu jego urządzeń budynek był nadal wykorzystywany do celów mieszkalnych, być może podnajmowany lokatorom. Dolegliwości, na które mogli oni cierpieć i łagodzili za pomocą łatwo dostępnych preparatów, to być może schorzenia powstałe wskutek dłuższego przebywania w złych warunkach mieszkaniowych.

Inne butelki pozyskane podczas badań były przeznaczone do rozmaitych napojów - piwa, wina i wody mineralnej. Dające się odczytać sygnatury to przede wszystkim oznaczenia miejscowych wytwórców: „A. Kusche Nchf. Paul Kahler Brauerei Lähn (Wleń)”, „Kusche Mineralwasserfabrik Lähn” i „Kusche Selters-u. Limonadenfabrik Lähn”. Co ciekawe, we wrześniu 1907 r. browar we Wleniu został wykupiony z rąk A. Kusche przez Paula Kahlera ${ }^{89}$. W związku z tym wiadomo, że niektóre z odnalezionych w warstwie pożarowej butelek wyprodukowano krótko przed zniszczeniem obiektu - między wrześniem 1907 a grudniem 1910 r. Potwierdzeniem konsumpcji piwa z Jeleniej Góry były fragmenty butelki i kapsle z sygnaturą „Hirschberger Brauhaus Angermüller \& Co.”.

Przy wejściu do budynku gospodarczego (nr 4), które znajdowało się przypuszczalnie w narożniku południowo-zachodnim, znaleziono duże ilości szkła okiennego i przedmiotów metalowych oraz cztery inne butelki (jedna z nich była zniszczona). Pojemniki te opatrzone były nazwami browarów: „J. Hochberg

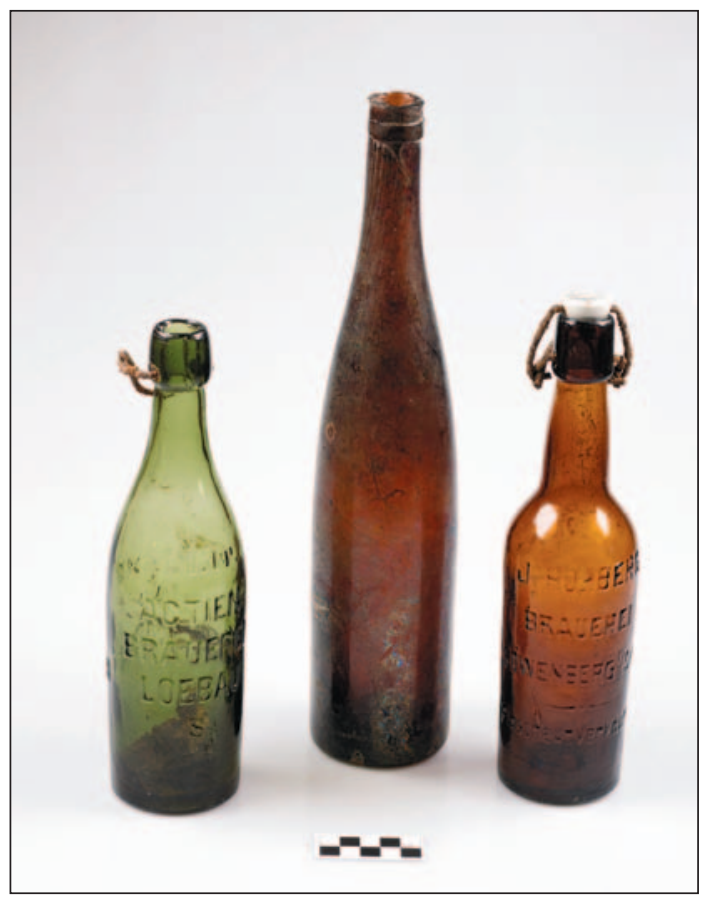

Ryc. 12. Bystrzyca, Młyn Dolny. Butelki szklane pozyskane z pomieszczenia $\mathrm{nr} 4$

(fot. B. Miazga)

Fig. 12. Bystrzyca, the Lower Mill. Glass bottles found in room 4 (photo by B. Miazga)

${ }^{88}$ Höger-Kunze S. 2014.

89 Verschiedenes. 1907. 
Brauerei Löwenberg in Schl.” (Lwówek Śląski) oraz „Actien Brauerei Loebau/S.” (Löbau w Saksonii) (ryc. 12). Interesującym znaleziskiem jest także figurka Marii z dzieciątkiem (o wysokości 8,1 cm) wykonana z porcelany, z częściowo zachowanymi śladami złoceń. Z kolei na jednym z porcelanowych kubków umieszczono żartobliwy napis: Trinke alle Morgen Dein Töpfchen ohne Sorgen.

Kryzys młynarstwa tradycyjnego i powstanie młynów opartych na nowszej technologii zazębiają się czasowo. Okresem wspólnej egzystencji, schyłkowej dla młynów z kołem wodnym i wstępnej dla młynów z turbiną wodną, parowych i elektrycznych (w końcówce stulecia) był wiek XIX.

Uprzemysłowienie regionu Pogórza Kaczawskiego i terenów sąsiednich rozpoczęło się przed połową tego stulecia i z czasem nabierało coraz większego tempa. Stawiano nie tylko wydajne młyny, w których instalowano silniki parowe, lecz wykupywano i przebudowywano stare młyny zbożowe, zmieniając całkowicie ich przeznaczenie. Szczególne znaczenie zyskał przy tym nowoczesny przemysł papierniczy. Najwcześniej, bo już w 1837 r., w zabudowaniach po młynie zbożowym uruchomiono produkcję papieru w Dąbrowicy koło Jeleniej Góry ${ }^{90}$. Podobny los spotkał w 1851 r. młyn zbożowy w Strupicach, gdzie powstała fabryka papieru wchodząca w skład spółki Gebrüder Erfurt. W 1853 r. jako kolejny zamieniono na papiernię młyn zbożowy w Piechowicach ${ }^{91}$. Natomiast początek XX w. to okres powszechnej elektryfikacji i regulacji rzeki Bóbr na niespotykaną wcześniej skalę. Powstały wielkie zapory w Pilchowicach i Leśnej, a w latach 1908-1912 uruchomiono przy nich elektrownie wodne ${ }^{92}$.

Studium przypadku niewielkiego Młyna Dolnego w Bystrzycy koło Wlenia ukazuje długotrwały, lecz nieuchronny proces upadku tradycyjnego młynarstwa związanego z tempem zmian technicznych, będących efektem trwającego od końca XVIII w. uprzemysłowienia. Procesy, które zapoczątkowano wtedy, miały zasięg globalny i były bezprecedensowe w historii rozwoju ludzkości. Opisywany obiekt jest jednym z wielu, które w granicach ówczesnego Śląska zostały wtedy zlikwidowane lub przekształcone, często tracąc swoją pierwotną funkcję. Razem z ich końcem zakończyła się era młynarstwa w takim kształcie, w jakim funkcjonowało ono od średniowiecza, a nastała nowa jakość przetwórstwa zboża.

Badania archeologiczne pozwoliły na rekonstrukcję planu młyna i określenie przeznaczenia funkcjonalnego większości z odkrytych pomieszczeń. Pośrednio wykazały także, że założenie jest kilkufazowe i przypuszczalnie kryje relikty starszego budynku. Na podstawie analizy odsłoniętych pozostałości i kamieni młyńskich dowiedziono, że mimo trudności kolejni właściciele podejmowali próby modernizacji swojej własności. Nie uchroniły one jednak młyna przed upadkiem, poprzedzonym pożarem w $1910 \mathrm{r}$.

Zarejestrowana w trakcie prac warstwa pożarowa zawierała dużą liczbę zabytków ruchomych. Świadczą one, że osoby mieszkające w młynie uczestniczyły w szerokiej sieci wymiany dóbr i pośrednio korzystały z udoskonaleń będących efektem produkcji przemysłowej. To swoisty paradoks, który z jednej strony doprowadził do redukcji tradycyjnych sposobów zarobkowania, z drugiej umożliwił intensyfikację wytwórczości i dostępność towarów na niespotykaną wcześniej skalę. To znak rozpoznawczy szerokich procesów, które można łączyć z ogólnym zjawiskiem industrializacji.

${ }^{90}$ Szymczyk M. 2001, s. 97.

${ }^{91}$ Szymczyk M. 2001, s. 103-105; Krajniak W. 2016, s. 141.

${ }^{92}$ Krajniak W. 2016, s. 148. 
Adresy Autorów:

dr Paweł Duma

Instytut Archeologii Uniwersytet Wrocławski

ul. Szewska 48

50-139 Wrocław

pawel.duma@uwr.edu.pl

https://orcid.org/0000-0001-7991-3133

prof. dr hab. Jerzy Piekalski

Instytut Archeologii Uniwersytet Wrocławski

ul. Szewska 48

50-139 Wrocław

jerzy.piekalski@uwr.edu.pl

https://orcid.org/0000-0002-8206-1856

dr hab. Agnieszka Latocha

Instytut Geografii i Rozwoju Regionalnego

Uniwersytet Wrocławski

pl. Uniwersytecki 1

50-137 Wrocław

agnieszka.latocha@uwr.edu.pl

https://orcid.org/0000-0001-7292-5043 mgr Marta Pietruszka

Instytut Archeologii Uniwersytet Wrocławski

ul. Szewska 48

50-139 Wrocław

marta.pietruszka2@uwr.edu.pl

https://orcid.org/0000-0002-1154-7357

dr hab. Krzysztof Jaworski

Instytut Archeologii Uniwersytet Wrocławski

ul. Szewska 48

50-139 Wrocław

krzysztof.jaworski@uwr.edu.pl

https://orcid.org/0000-0001-7128-8812

mgr Maksym Mackiewicz

Fundacja Archeolodzy.org

ul. Bolesława Prusa 81/3i

50-316 Wrocław

Centrum Archeologii Śródziemnomorskiej

Uniwersytet Warszawski

ul. Prosta 69

00-838 Warszawa

maksym.mackiewicz@uw.edu.pl

https://orcid.org/0000-0003-2509-4739

\section{BIBLIOGRAFIA}

\section{Źródła archiwalne}

Ablösung der Mühldienste. 1855. „Ablösung der Mühldienste an Ober und Nieder Wiesenthal, Kreis Löwenberg”, Archiwum Państwowe we Wrocławiu, Krajowy Urząd Kultury Rolnej we Wrocławiu, sygn. 764.

Siebenhaar Ernst. 1906. „Chronik des Dorfes Wiesenthal”, rękopis, własność prywatna (kopia w posiadaniu Doris Baumert).

Regler Ludwig Wilhelm. 1764-1770. Schlesien, links der Oder ohne Grafschaft Glatz, Staatsbibliothek zu Berlin, Preußischer Kulturbesitz, Kartenabteilung.

Urmesstischblätter. 1823-1824. Urmesstischblätter, Staatsbibliothek zu Berlin, Preußischer Kulturbesitz, Kartenabteilung.

Wrede Christian Friedrich. 1747-1753. Krieges-Carte von Schlesien, Staatsbibliothek zu Berlin, Preußischer Kulturbesitz, Kartenabteilung.

\section{Źródła i opracowania publikowane}

Appelt Heinrich. 1939. Zur Siedlungsgeschichte der Kastellanei Lähn, „Zeitschrift für Geschichte Schlesiens”, 73, s. 1-10.

Auktion. 1863. Auktion. Der Bote aus dem Riesengebirge, 62, s. 1343.

Bagniewski Zbigniew, Kubów Piotr. 1977. Średniowieczny mlyn wodny z Ptakowic na Dolnym Śląsku, „Kwartalnik Historii Kultury Materialnej”, R. XXV, nr 1, s. 3-31.

Baranowski Bogdan. 1971. Rozmiary i rejonizacja przemysłu mlynarskiego w Polsce w XVI-XVIII w., „Zeszyty Naukowe Uniwersytetu Łódzkiego”, t. 75, s. 15-37.

Baranowski Bogdan. 1977. Polskie mlynarstwo, Wrocław. 
Bartyś Julian. 1970. Zmiany w technice urządzeń mielących od XVII do początków XX wieku, „Studia z dziejów gospodarstwa wiejskiego”, t. 12, s. 101-178.

Baumert Doris. 2017. Wiesenthal, Kreis Löwenberg (Schlesien). Kurze Ortsgeschichte anlässlich der 800-Jahr-Feier am 3. Juni 2017, Nürnberg.

Bedwin Owen. 1980. The Excavation of Batsford Mill, Warbleton, East Sussex, 1978, „Medieval Archaeology”, 24 (1), s. 187-201.

Behrens Ernst C. 1789. Die practische Mühlen-Baukunst oder gründliche und vollständige Anweisung zum Mühlen- und Mühlen-Grundwerks-Baue mit den Haupt- und Specialrissen [...], Schwerin.

Bender Witold. 1974. Młyn z początku XIII wieku na południowym Mazowszu, „Kwartalnik Historii Kultury Materialnej”, R. XXII, nr 2, s. 213-229.

Bennett Rebecca, Welham Kate, Hill Ross A., Ford Andrew. 2012. A comparison of visualization techniques for models created from airborne laser scanned data, „Archaeological Prospection”, 19 (1), s. 41-48.

Berthold Jens. 2015. Mühlen im Befund — Eine Übersicht zu archäologischen Erscheinungsformen von Wassermühlen, [w:] Wassermühlen und Wassernutzung im mittelalterlichen Ostmitteleuropa, red. M. Maříková, Ch. Zschieschang, Forschungen zur Geschichte und Kultur des östlichen Mitteleuropa, t. 50, Stuttgart, s. 235-268.

Berthold Jens. 2016. Grundlagen der Archäomolinologie: Aspekte archäologischer Mühlenkunde, „Mitteilungen der Deutschen Gesellschaft für Archäologie des Mittelalters und der Neuzeit”, 29, s. 113-124.

Błoński Mariusz, Żukowski Robert. 2019. Relikty pomostu średniowiecznego mlyna w Nasielsku, „Kwartalnik Historii Kultury Materialnej”, R. LXVII, nr 3, s. 381-394.

Brykała Dariusz, Podgórski Zbigniew. 2020. Evolution of landscapes influenced by watermills, based on examples from Northern Poland, „Landscape and Urban Planning”, 198, s. 1-15.

Buczek Karol. 1969. Z dziejów mlynarstwa w Polsce średniowiecznej, „Studia Historyczne”, t. 12, nr 1, s. 17-51.

Champagne Frédéric, Ferdière Alain, Rialland Yannick. 1997. Re-découverte d'un moulin à eau augustéen sur l'Yèvre (Cher) / The rediscovery of an augustan water-mill on the river Yèvre (Cher), „Revue archéologique du Centre de la France”, 36 (1), s. 157-160.

Choroś Monika, Jarczak Łucja. 2015. Schlesische Orts- und Flurnamen mit dem Glied Mühle/mlyn, [w:] Wassermühlen und Wassernutzung im mittelalterlichen Ostmitteleuropa, red. M. Maříková, Ch. Zschieschang, Forschungen zur Geschichte und Kultur des östlichen Mitteleuropa, t. 50, Stuttgart, s. 173-192.

Chorowska Małgorzata, Duma Paweł, Furmanek Mirosław, Legut-Pintal Maria, Łuczak Anna, Piekalski Jerzy. 2017. Wleń/Lähn District in the Sudetes Foothills, Poland: A Case Study of Cultural Landscape Evolution of an East Central European Settlement Microregion From the Tenth to the Eighteenth Centuries, „International Journal of Historical Archaeology”, 21 (1), s. $66-106$.

Crossley David W. 1994. Post-medieval archaeology in Britain, London.

Dembińska Maria. 1973. Przetwórstwo zbożowe w Polsce średniowiecznej, Wrocław.

Downward Stuart, Skinner Kevin. 2005. Working Rivers: The Geomorphological Legacy of English Freshwater Mills, „Area”, 37 (2), s. 138-147.

Duma Paweł. Latocha Agnieszka, Łuczak Anna, Piekalski Jerzy. 2020. Stone Walls as a Characteristic Feature of the Cultural Landscape of the Izera Mountains, southwestern Poland, „International Journal of Historical Archaeology”, 24 (1), s. 22-43.

Duma Paweł, Łuczak Anna, Piekalski Jerzy. 2019. Kopaniec in the Izera Mountains An example of unusual transformation in a village after the Thirty Years' War period in Silesia (1618-1648), [w:] Settlement Change Across Medieval Europe. Old Paradigms and New Vistas, red. N. Brady, C. Theune, Ruralia XIII, Leiden, s. 331-340.

Fajer Maria, Waga Jan M. 2017. Mlyny wodne — zanikajacy element krajobrazu dolin rzecznych (na przykładzie Wyżyny Woźnicko-Wieluńskiej, [w:] Młynarstwo tradycyjne - wczoraj, dziś, jutro... Problemy zachowania ginacego dziedzictwa, red. A. Przybyła-Dumin, B. Grabny, P. Roszak-Kwiatek, Chorzów, s. 117-139. 
Feldhaus Franz M. 1914. Die Technik der Vorzeit, der geschichtlichen Zeit und der Naturvölker; ein Handbuch für Archäologen und Historiker, Museen und Sammler, Kunsthändler und Antiquare, Leipzig-Berlin.

Feuer. 1910. Feuer, „Lähner Anzeiger”, 10 grudzień, s. 2.

Fokt Krzysztof. 2012. Późnośredniowieczne osadnictwo wiejskie na Dolnym Śląsku w świetle badań archeologicznych, Kraków.

Frančić Mirosław. 1954. Technika mlynów wodnych w Polsce, „Kwartalnik Historii Kultury Materialnej”, R. II, nr 1-2, s. 79-103.

Galusová Lucie. 2011. Archeologický výzkum vodních mlýnů: výsledky, perspektivy, „Antropo Webzin”, 2, s. 113-120.

Galusová Lucie. 2015. Vodní mlýn jako objekt archeologického výzkumu, „Archaeologia historica”, 40 (1), s. 267-293.

Gordon Robert B., Malone Patrick M.. 1997. The Texture of Industry. An Archaeological View of Industrialization of North America, New York-Oxford.

Górzyńska Agnieszka, Górzyński Tomasz, Majewski Maciej. 2011. Późnośredniowieczny młyn z Mniszka na ziemi świeckiej ze stanowiska 16, „Raport”, 2005-2006, s. 59-68.

Hesse Ralf. 2013. The changing picture of archaeological landscapes: lidar prospection over very large areas as part of a cultural heritage strategy, [w:] Interpreting Archaeological Topography, 3D Data, Visualisation and Observation, red. R.S. Opitz, D.C. Cowley, Oxford, s. 171-183.

Härtel Hans. 1941. Ländliche Baukultur am Rande der Mittelsudeten: als Beitrag zur Landesbaupflege in Schlesien, Schlesische Heimat, t. 6, Breslau.

Höger-Kunze Susanne. 2014. Kleine Flaschen und der Handel mit Olitäten aus dem Thüringer Wald, „Pressglas-Korrespondenz”, 52 (3), s. 1-9.

Holt Richard. 1988. The mills of medieval England, Oxford-New York.

Jaccottey Luc, Labeaune Régis. 2010. Découverte d'un moulin hydraulique aypisachntique à Longvic (Côte-d'Or), „Revue archéologique de l'Est”, 59 (2), s. 665-668.

Jeute Gerson H. 2015. Zur Verbreitung der hochmittelalterlichen Mühle aus archäologischer Sicht, [w:] Wassermühlen und Wassernutzung im mittelalterlichen Ostmitteleuropa, red. M. Maříková, Ch. Zschieschang, Forschungen zur Geschichte und Kultur des östlichen Mitteleuropa, t. 50, Stuttgart, s. 269-278.

Kaczyński Bartłomiej. 2017. Dawny młyn wodny „Patorra” w świetle badań wykopaliskowych przeprowadzonych latem 2012 roku, na stanowisku XXI w Szkotowie, pow. nidzicki, „Komunikaty Mazursko-Warmińskie”, t. 295 (1), s. 109-156.

Kiarszys Grzegorz, Szalast Grzegorz. 2014. Archeologia w chmurze punktów. Porównanie rezultatów filtracji i klasyfikacji gruntu w projekcie ISOK z wynikami opracowanymi w oprogramowaniu LAStools i Terrasolid, „Folia Praehistorica Posnaniensia”, t. 19, s. 267-292.

Kizik Edmund. 2008. Młyny w Ekonomii Malborskiej według inwentarzy z lat 1755 i 1765, „Kwartalnik Historii Kultury Materialnej”, R. LVI, nr 3-4, s. 397-404.

Knoblich Augustin. 1863. Chronik von Lähn und Burg Länhaus am Bober. Urkundliche Beiträge zur Geschichte der Städte, Ritterburgen, Fürsten, und Adelsgeschlechter Schleseins, Breslau.

Kouschil Christa. 2000. Mlynarstwo a rozwój społeczny w średniowieczu, [w:] Niebezpieczne drogi i podejrzani mlynarze, red. Z. Czarnuch, D.A. Rymar, Gorzów Wielkopolski, s. 107-121.

Kowalczyk Andrzej, Paprocki Dariusz. 2012. Relikty nowożytnego kompleksu mlyńskiego w Raduszynie, gm. Murowana Goślina, pow. poznański, „Wielkopolskie Sprawozdania Archeologiczne”, t. 13, s. $153-160$.

Krajniak Wiktor. 2016. Między mlynarstwem a elektryfikacją. Społeczno-gospodarcze uwarunkowania wykorzystania potencjału energetycznego rzeki Bóbr od średniowiecza do 1945 roku, „Roczniki Dziejów Społecznych i Gospodarczych”, R. 76, s. 121-163.

Kubicki Rafał. 2012. Młynarstwo w państwie zakonu krzyżackiego w Prusach w XIII-XV wieku (do 1454 r.), Gdańsk.

Kwaśny Zbigniew. 1959. Młyny zbożowe w majatkach Schaffgotschów na początku XVIII wieku, „Śląski Kwartalnik Historyczny Sobótka”, t. 14 (4), s. 487-498.

Leveau Philippe. 1996. The Barbegal Water Mill in Its Environment: Archaeology and the Economic and Social History of Antiquity, „Journal of Roman Archaeology”, 9, s. 137-153. 
Lisowska Ewa, Gunia Piotr, Borowski Michał. 2014. Production and distribution of rotary quernstones from quarries in southwestern Poland in the early Middle Ages, [w:] Seen through a millstone, AmS-Skrifter, red. L. Selsing, Stavanger, s. 167-180.

Loewe Ludwig. 1969. Schlesische Holzbauten, Düsseldorf.

Łuczak Czesław. 1950. Technika przemysłu spożywczego w Poznaniu w XVIII wieku, „Roczniki Dziejów Społecznych i Gospodarczych”, R. 12, s. 69-104.

Maleczyńska Kazimiera. 1961. Dzieje starego papiernictwa śląskiego, Monografie Śląskie, t. 4, Wrocław.

Mosse John. 1967. The Albion Mills 1784-1791, „Transactions of the Newcomen Society”, 40 (1), s. 47-60.

Mühlen-Ordnung. 1777. Mühlen-Ordnung für das Souveraine Herzogthum Schlesien und die Graffschaft Glatz, Breslau.

Myśliwski Grzegorz. 2003. Utilization of water in the Central Europe (12th-16th centuries), [w:] Economia e energia, secc. XIII-XVIII : atti della „Trentaquattresima settimana di studi”, 15-19 aprile 2002, red. S. Cavaciocchi, Firenze, s. 321-334.

Notebaart Jannis C. 1972. Windmühlen: Der Stand der Forschung über das Vorkommen und den Ursprung, Paris.

Orser Charles E. 2002. Windmills, [w:] Encyclopaedia of Historical Archaeology, red. Ch.E. Orser, London-New York, s. 574-575.

Palmer Marilyn, Nevell Michael, Sissons Mark. 2012. Industrial archaeology: a handbook, York.

Peuckert Will E. 1928. Schlesische Volkskunde, Heidelberg (reprint: Franfurt/Main 1978).

Podwińska Zofia. 1970. Rozmieszczenie wodnych młynów zbożowych w Małopolsce w XV wieku, „Kwartalnik Historii Kultury Materialnej”, R. XVIII, nr 3, s. 373-402.

Raistrick Arthur. 1972. Industrial Archaeology: An Historical Survey, London.

Reynolds Terry S. 1983. Stronger Than a Hundred Men: A History of the Vertical Water Wheel, Baltimore-London.

Rospond Stanisław. 1968. Stownik etymologiczny nazw geograficznych Śląska, t. 1: A-B. Warszawa-Wrocław.

Rynne Colin. 2007. The archaeology of power and industry, [w:] The Post-Medieval Archaeology of Ireland 1550-1850, red. A. Horning, R.Ó. Baoill, C. Donnelly, P. Logue, Dublin, s. 241-261.

Rzepkowski Krzysztof. 2015. Złoty kciuk: mlyn i mlynarz w kulturze Zachodu, Warszawa-Toruń.

Samsonowicz Henryk. 1954. Rzemiosło wiejskie w Polsce XIV-XVII w., Warszawa.

Sánchez-Jiménez Francisco J., González José A. 2018. Watermills: The Origin of the Use of Renewable Hydraulic Energy in Spain, „Industrial Archaeology Review”, 40 (1), s. 2-10.

Schneider Jan G. 1794. Dalsze poprawne y pomnożone mlyno-budownictwo. Część 1, Warszawa.

Schmuck Adam. 1957. Regiony termiczne województwa wrocławskiego, „Czasopismo Geograficzne”, t. 28 (3-4), Wrocław.

Seen through a millstone. 2014. Seen through a millstone. AmS-Skrifter, red. L. Selsing, Stavanger.

Sochacka Stanisława. 2015. Die Namen der Wassermühlen in Schlesien, [w:] Wassermühlen und Wassernutzung im mittelalterlichen Ostmitteleuropa, red. M. Maříková, Ch. Zschieschang, Forschungen zur Geschichte und Kultur des östlichen Mitteleuropa, t. 50, Stuttgart, s. $163-172$.

Sowina Urszula. 2009. Woda i ludzie w mieście późnośredniowiecznym i wczesnonowożytnym: ziemie polskie z Europa w tle, Warszawa.

Strahler Arthur N. 1957. Quantitatives analysis of watershed geomorphology, „Transactions of the American Geophysical Union”, 38 (6), s. 913-920.

SUB. 1971. Schlesisches Urkundenbuch, t. 1, wyd. H. Appelt, Wien-Köln-Graz.

Szymczyk Maciej. 2001. Dzieje jeleniogórskiego ośrodka przemysłu papierniczego (cz. 1: do 1945 r.), „Rocznik Jeleniogórski”, R. 33, s. 95-114.

Trawkowski Stanisław. 1959. Młyny wodne w Polsce w XII wieku, „Kwartalnik Historii Kultury Materialnej”, R. VII, nr 1, s. 62-86.

Tucker Gordon D. 1982. Millstones North and South of the Scottish Border, „Industrial Archaeology Review”, 6 (3), s. 186-193. 
Verschiedenes. 1907. Lähn, 13. August (Verschiedenes), „Der Bote aus dem Riesengebirge”, 15 sierpień, s. X.

Ward Owen H. 1982. Millstones from La Ferté-sous-Jouarre, France, „Industrial Archaeology Review”, 6 (3), s. 205-210.

Wesołowska Henryka. 1969. Młynarstwo wiejskie Opolszczyzny od XVIII do XX wieku, Opole.

Wężyk Piotr 2015. Podręcznik dla uczestników szkoleń z wykorzystania produktów LiDAR, Warszawa.

Wiatrowski Leszek. 1974. Przemiany gospodarki folwarcznej i chłopskiej na Śląsku w okresie reform agrarnych $w X I X$ w., Wrocław.

Wiśniewski Jerzy. 1970. Nazwy młynów w Polsce, „Kwartalnik Historii Kultury Materialnej”, R. XVIII, nr 3, s. 449-455.

Zientara Benedykt. 2006. Henryk Brodaty i jego czasy, wyd. 3, Warszawa.

Związek Tomasz. 2014. Kształtowanie sieci młynów wodnych na przykładzie powiatu konińskiego (ok. 1300-1550), „Studia Geohistorica”, t. 2, s. 118-142.

The Lower Mill in Bystrzyca. The crisis of traditional milling in the time of industrialization

In 2019 a research team from the Institute of Archaeology of the University of Wrocław excavated relics of a watermill, probably built in the second half of the 18th c., in the village of Bystrzyca (German Wiesenthal) near the town of Wleń in Pogórze Kaczawskie (German BoberKatzbach-Vorgebirge), part of the Western Sudetes. A schematic picture of the mill was included in a map prepared by L.W. Regler in 1764-1770. The mill, called Młyn Dolny (the Lower Mill), was powered by the stream Wierzbnik (German Würfelbach), which has its source in the Kaczawskie (Katzbach) Mountains and flows into the River Bóbr (Bober) $2.5 \mathrm{~km}$ to the west from the location of the mill. The mill stopped working before 1896 and served as a dwelling house for a short time; on the 7th of December 1910, several years after its abandonment, it was completely destroyed by a fire (probably resulting from arson). In the present article its history serves as an illustration of a wide and universal economic and cultural phenomenon evidenced in Central and Eastern Europe in the 19th c., namely the crisis of traditional milling based on natural energy sources — hydropower and wind power.

The research was based on sources and methods drawn from several disciplines, mainly archaeology, history and geography, combined within the framework of historical archaeology. The sources analysed included local written accounts and cartographic materials alongside archaeological finds.

Just before the industrial revolution, i.e. in the last quarter of the 18th c., Silesia, being part of Prussia then, had 5152 mills (with 66\% of watermills and 34\% of windmills), located mostly in the country (estimates from 1787). Only 344 mills (6.7\%) were situated in towns. Due to landform features, it was windmills that dominated in the lowlands of northern Silesia, and watermills, situated on rapid rivers and streams, in the highland region close to the Sudetes. Quite frequently, there were several mills in a single village; for instance in Bystrzyca there were two watermills and a windmill, with further mills located nearby in Wleń, Gościradz and Rząśnik.

The owners and leaseholders of those small workshops had to face a new global-scale phenomenon, which started in the USA in 1785 - the emergence of large mechanized mills. Those new enterprises differed from traditional mills with regard to the structure (they were not family businesses but large industrial plants manned by hired workers), production scale (in the second half of the $19^{\text {th }}$ c. the milling capacity of an industrial mill was over 200 times bigger 
than that of a traditional mill), energy sources (steam engines, and from the last quarter of the 19th c also electrical engines), locations (the production moved to urban and suburban areas) and clientele (mostly the inhabitants of industrial urban centres, whose numbers grew rapidly due to the migration from the country to towns).

The first industrial mill in Silesia was built in 1816 in Wałbrzych (German Waldenburg), which was then the main industrial centre in the whole of Silesia, with a variety of industries represented (coal mining, numerous quarries, the largest centre of china production in Prussia, glass industry, textile production, etc.).

The number of watermills and windmills in Silesia decreased significantly throughout the 19th c. In 1818, i.e. not long after the opening of the steam mill in Wałbrzych, 5929 mills were registered, whereas in 1907 there were only 3033, which was an almost 50\% drop. The richest of small millers tried to fight off competition by modernizing their enterprises; one of the ways was to invest in new, more cost-efficient millstones from the quartzite quarry in Férte-sous-Jouarre in France, which were supplied to many countries of continental Europe, as well as to Great Britain and the USA. At least one set of those characteristic segmental "French" millstones produced of specially bonded trapezium-shaped blocks of quartzite was imported in the 19th c. to the mill in Bystrzyca to replace its millstones made of local sandstone. The old millstones were re-used as building material when the mill was restructured.

In retrospect, the investment in the exchange of millstones can be viewed as an attempt to save a family business; unfortunately, an unsuccessful one. Most of the small mills in Silesia were liquidated or transformed, having lost its original function before the onset of the 20th c., as the Lower Mill in Bystrzyca. Few mills survived World War I, combining production with some other trade, e.g. tourist services. Their decline marked the end of traditional milling, which had functioned in Silesia since the Middle Ages.

Proofread by Izabela Szymańska 